2019-01-01

Dual wave farms and coastline dynamics: The role of inter-device spacing

Rodriguez-Delgado, C

http://hdl.handle.net/10026.1/12369

10.1016/j.scitotenv.2018.07.110

Science of the Total Environment

Elsevier

All content in PEARL is protected by copyright law. Author manuscripts are made available in accordance with publisher policies. Please cite only the published version using the details provided on the item record or document. In the absence of an open licence (e.g. Creative Commons), permissions for further reuse of content should be sought from the publisher or author. 


\title{
Dual wave farms and coastline dynamics: the role of inter-device spacing
}

\author{
Cristobal Rodriguez-Delgado ${ }^{\mathrm{a}}$, Rafael J. Bergillos ${ }^{\mathrm{b}}$, Gregorio Iglesias ${ }^{\mathrm{a}, *}$ \\ ${ }^{a}$ School of Engineering, University of Plymouth, Plymouth PL4 8AA, UK \\ ${ }^{b}$ Andalusian Institute for Earth System Research, University of Granada, Avda. del \\ Mediterráneo, s/n, 18006 Granada, Spain
}

\begin{abstract}
In dual wave farms, i.e., arrays of wave energy converters (WECs) with a dual function - generation of renewable power and mitigation of coastal erosion - the spacing between the WECs is a fundamental design parameter. The present research has the objective of establishing how this parameter affects the shoreline evolution behind the array and, on this basis, to propose and apply a method to determine the optimum spacing for coastal protection. The method is demonstrated on a beach subjected to severe erosion. Five case studies are considered: four with different inter-WEC spacings, and one without the wave farm (baseline). A spectral wave propagation model is applied to analyse the variations in significant wave height behind the WEC array. Longshore sediment transport rates are calculated, and a shoreline model is applied. We find that in all the case studies the dry beach area is greater than in the baseline (no farm) case study, which proves the capacity of the dual WEC array to mitigate the erosive trends of the system. Importantly, we obtain that the inter-WEC spacing plays a fundamental role in the evolution of the shoreline and, consequently, in the effectiveness of the WEC array for coastal protection. The case studies with intermediate spacings yield the best performance in terms of dry beach area. More generally, the benefits of dual wave farms in terms of protection of coastal properties and infrastructure, and the ensuing savings in conventional coastal
\end{abstract}

\footnotetext{
* Corresponding author

Email address: gregorio.iglesias@plymouth.ac.uk (Gregorio Iglesias)
} 
defence measures (coastal structures, beach nourishment, etc.) contribute to the development of wave energy by enhancing its economic viability. The methodology presented in this paper can be used to optimize the design of dual wave farms elsewhere.

Keywords: Wave energy; coastal defence; erosion; sediment transport; shoreline evolution; sustainable development

1

2 3

4

7

8

9

\section{Introduction}

In the last decade, the exploitation of renewable energy resources as sustainable alternatives to fossil fuels has received increasing research interest [1, 2]; indeed, the replacement of carbon fuels by carbon-free alternatives is one of the main challenges that society will face in the XXI century 3 . Among the different renewable energy sources, wave energy is becoming more important thanks to the extensive worldwide resource 4] and comparatively low environmental impacts [5].

Previous works on wave energy have concentrated on: the development of the technology [6 13], the assessment and characterization of the resource [1427], the selection of potential sites [28 31], the economics [32 35], the synergies with other renewable energy sources [36 40] and the environmental impacts, as described below.

Wave farms modify wave propagation patterns and, therefore, the spatial distribution of wave heights [41 43, which may be used for erosion control and coastal protection [44, 45]. Dual wave farms, i.e., wave farms with the dual purpose of renewable energy production and coastal protection, have been recently proposed [46]. One of the areas where dual wave farms may be useful are deltaic coasts, which have been particularly affected by erosion in recent decades, in part due to human interventions (river damming) in their catchment areas [47 52], in part due to climate change [53 55].

The impacts of wave farms on the dynamics of sandy beaches have been extensively addressed [56, 60]. However, the alterations of wave farms on mixed 
and gravel-dominated coasts, which are common on high-latitudes and steep hinterlands coasts worldwide, have been comparatively less studied. In particular, to our best knowledge, the effects caused by the spacing between wave energy converters (WECs) on wave height and longshore sediment transport (LST) have not been addressed so far.

This work has a fundamental objective, namely to investigate the effects of the inter-WEC spacing on wave propagation, LST patterns and coastline evolution. For this purpose, we applied a wave propagation model (SWAN) previously calibrated for the study site; the output of this model was used to assess the LST rates and, on this basis, a shoreline model was run for each case study.

\section{Study Site}

Playa Granada is a 3-km-long gravel-dominated beach located on the southern coast of Spain that faces the Mediterranean Sea (Figure 1). The beach corresponds to the central stretch of the Guadalfeo deltaic coast and is bounded to the west by the Guadalfeo River mouth and to the east by Punta del Santo, the former location of the river mouth 61. The deltaic coast is bounded to the west by Salobreña Rock and to the east by Motril Port.

The Andalusian littoral of the Mediterranean Sea is characterized by the presence of high mountainous relief and short fluvial streams, and the main contributor of sediments to the beach is the Guadalfeo River. Its basin has an area of $1252 \mathrm{~km}^{2}$ and includes the highest peaks on the Iberian Peninsula ( 3400 m.a.s.l.). Consequently, the river is associated with one of the most high-energy drainage systems along the Spanish Mediterranean coast 62].

The river was dammed $19 \mathrm{~km}$ upstream from the mouth in 2004, regulating $85 \%$ of the basin runoff 63 . The total capacity of the Rules' Reservoir $\left(117 \mathrm{hm}^{3}\right)$ was planned to be used for the following purposes: irrigation $(40 \%)$, supplies for residential developments along the coast (19\%), energy generation (9\%), flood control (30\%) and environmental flow (2\%). However, the river 


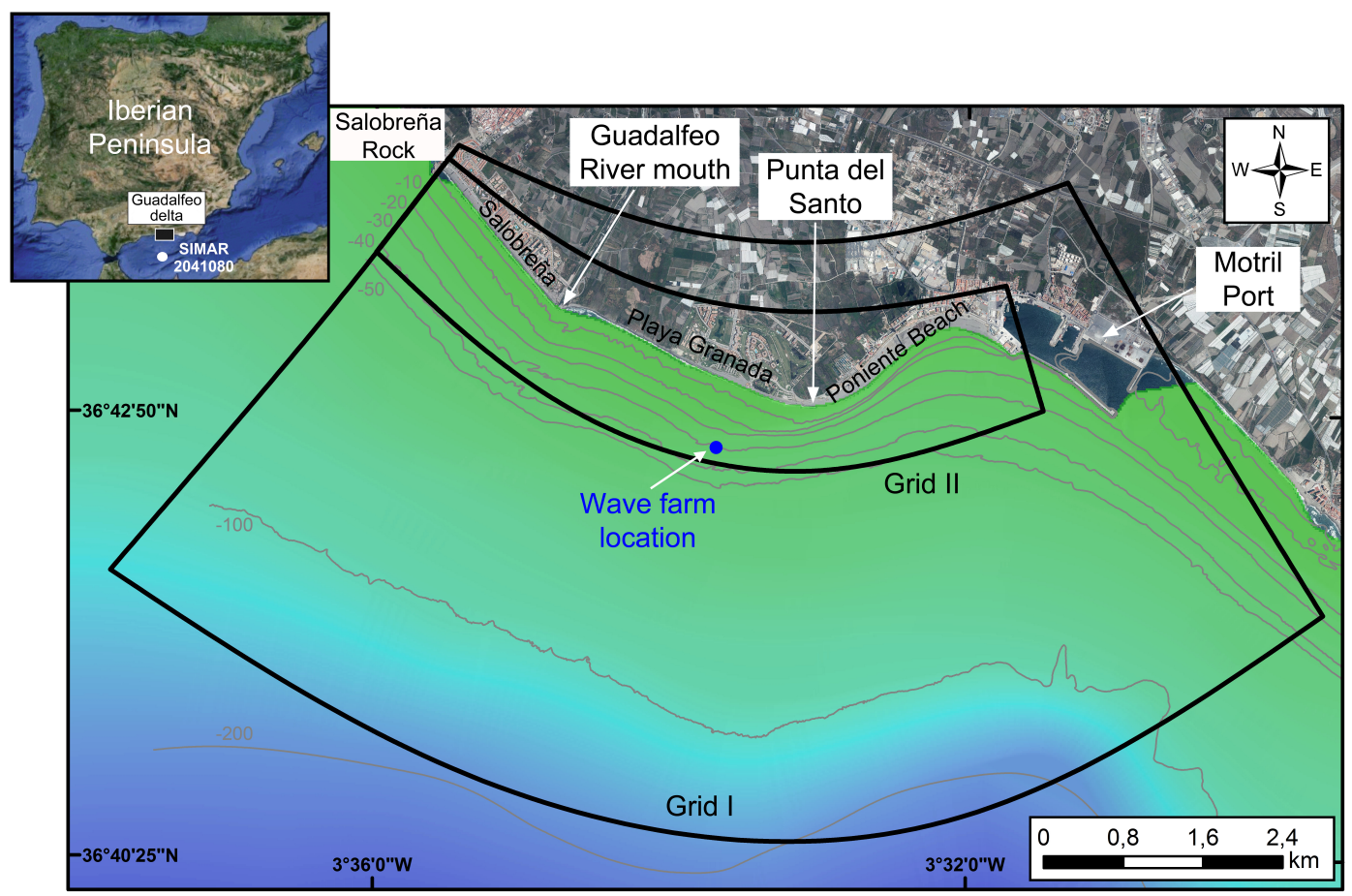

Figure 1: Upper left panel: Location of the study site (Guadalfeo delta, southern Spain). Central panel: bathymetric contours, grids used in the wave propagation model, position of the wave farm and location of the Salobreña Rock, Guadalfeo River mouth, Playa Granada, Punta del Santo, Poniente Beach and Motril Port.

damming modified the natural flow regime and altered the behaviour of the sys- 


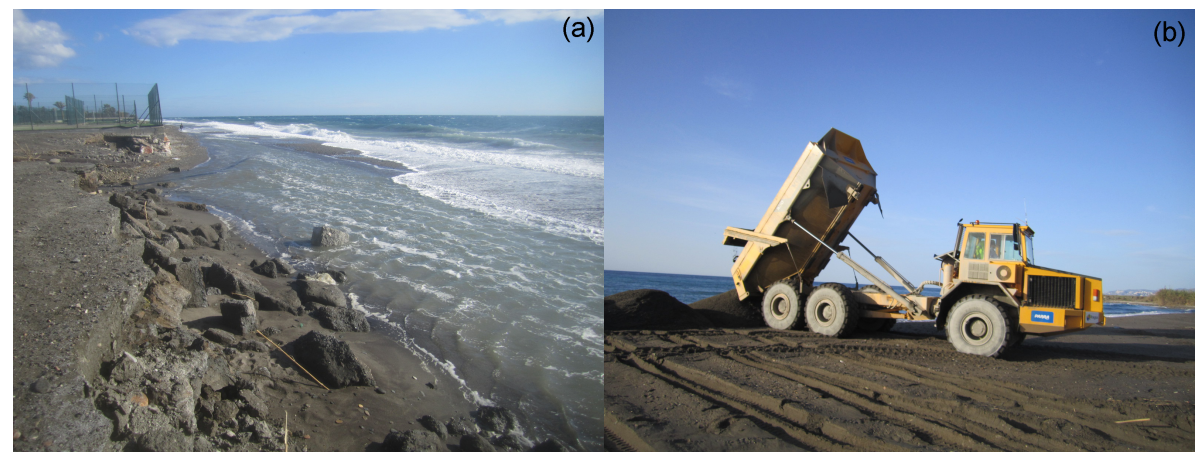

Figure 2: Terminal erosion (a) and renourishment works (b) in Playa Granada.

However, the success of these interventions has been very limited since they lasted on average less than three months [68, 69.

Climatic patterns at the study sites exhibit a significant contrast between summer and winter. The region is subjected to the passage of extra-tropical Atlantic cyclones and Mediterranean storms, with average wind speeds of 18-22 $\mathrm{m} / \mathrm{s}$ [70, which generate wind waves under fetch-limited conditions (approximately $300 \mathrm{~km}$ ). The storm wave climate is distinctly bimodal with the prevailing west-southwest (extra-tropical cyclones) and east-southeast (Mediterranean storms) wave directions [71]. Peak significant wave heights during typical and extreme storm events exceed $2.1 \mathrm{~m}$ and $3.1 \mathrm{~m}$, respectively [72. The astronomical tidal range is $\sim 0.6 \mathrm{~m}$ (micro-tidal conditions), whereas typical storm surge levels can exceed $0.5 \mathrm{~m}[73$.

\section{Materials and methods}

To investigate the effects of the inter-WEC spacing, four sea states were considered with the WEC array (Section 3.1), defined as combinations of the two prevailing wave directions ( $\mathrm{E}$ and $\mathrm{W})$ and low and high energy conditions ( $H_{s}=0.5 \mathrm{~m}$ and $H_{s}=3.1 \mathrm{~m}$, with $50 \%$ and $99.9 \%$ non-exceedance probability, respectively). They were modelled by means of the joint application of the wave propagation model SWAN [74, the LST formulation proposed by [75] and the one-line model [76] considering four different case studies (Section 3.1]. The 
Table 1: Parameters of the sea states modelled: significant wave height $\left(H_{s}\right)$, spectral peak period $\left(T_{p}\right)$ and mean wave direction $(\theta)$ in deep water.

\begin{tabular}{cccccc}
\hline & \multicolumn{2}{c}{ Low } & \multicolumn{2}{c}{ High energy } \\
& East & West & East & West \\
\cline { 2 - 6 } & $H_{s}(\mathrm{~m})$ & 0.5 & 0.5 & 3.1 & 3.1 \\
$T_{p}(\mathrm{~s})$ & 4.5 & 4.5 & 8.4 & 8.4 \\
$\theta\left(^{\circ}\right)$ & 107 & 238 & 107 & 238 \\
\hline
\end{tabular}

parameters for the four sea states were defined on the basis of the most frequent values of peak period and wave direction associated with the above significant wave heights (Table 1). With a view to establishing the effects of the persistence of the sea state on the trends of the coastline and dry beach area, each of the four case studies thus defined was modelled for four different values of persistence (12h, 24h, 36h, 48h).

\subsection{Definition of the case studies}

To analyze the effects of inter-WEC spacing $(S)$ on wave transmission, LST and the evolution of the coastline, four case studies (CS) were defined. The overtopping WEC device WaveCat, developed by [77, was considered, since it has been widely demonstrated to be efficient for coastal defence [43, 44, 59, 60].

The selected wave farm case studies have the same number of WECs (11) and rows (2), but different spacings between WECs: $D, 2 D, 3 D$, and $4 D$ (Figure 3 , with $D=90 \mathrm{~m}$ [58]. The geometrical centres of the defined case studies are all located at the same position (Figure 1), which was found to be optimum from the standpoint of the wave power available to the WECs 31; whereas the selected number of WECs and layout have been proved to be adequate for coastal protection purposes in recent years [43, 58, 78, 79].

\subsection{Wave propagation model}

Wave transmission from deep water to the nearshore was computed by means of the SWAN model [74]. This model was previously calibrated and validated 


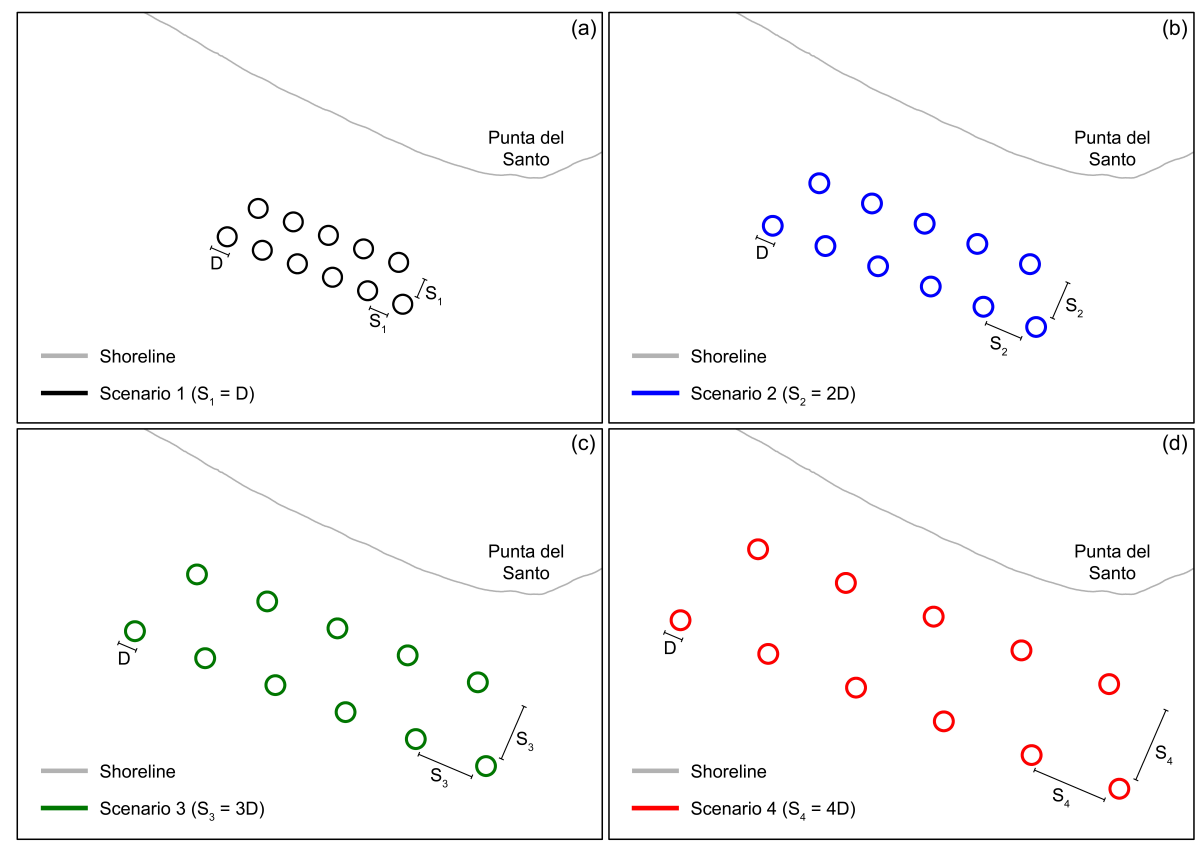

Figure 3: Definition of the four case studies.

for the study site by 68 through comparison with hydrodynamic data measured during extensive field surveys.

The two computational grids used for the calibration and validation process, shown in Figure 1, were also used in this work. Grid I is a coarse $82 \times 82$-cell grid covering the deltaic region, with cell sizes varying from $170 \times 65 \mathrm{~m}$ to $80 \times 80 \mathrm{~m}$. Grid II is a finer nested grid of $244 \times 82$ cells covering the area of the wave farm location, with cell sizes of about $25 \times 15 \mathrm{~m}$. This finer grid allows modelling properly the effects of the wave farm on wave propagation. The spectral resolution of the frequency space consisted of 37 logarithmically distributed frequencies ranging from 0.03 to $1 \mathrm{~Hz}$; whereas for the directional space 72 directions in increments of $5^{\circ}$ were considered to cover the $360^{\circ}$.

The interaction between WECs and wave field was modelled through the transmission $\left(K_{t}\right)$ and reflection $\left(K_{r}\right)$ coefficients, which were chosen on the basis of physical modelling of the WaveCat [9] and numerical modelling of the interaction between the wave farm and the wave field [43, 44, 59, 60]. The Motril 
Port and the Guadalfeo river jetties were also modelled as artificial obstacles. Based on the results from the wave model, two main tasks were performed: the role of the inter-WEC spacing in wave transmission was established, and the wave breaking variables were determined for the application of the LST formulation (Section 3.3).

To quantify the changes in the significant wave height at breaking with respect to the natural (no farm) case study, the non-dimensional significant wave height reduction was used. This parameter is defined as,

$$
\eta=1-\left(\frac{H_{s, b r}}{H_{s, b r 0}}\right),
$$

where $H_{s, b r}$ and $H_{s, b r 0}$ stand for the breaking significant wave height, respectively, in the case study in question and in the baseline.

\subsection{Longshore sediment transport formulation and one-line model}

LST rates were quantified through the following formulation, which was proposed by [75]:

$$
Q_{m}=0.00018 K_{\text {swell }} \rho_{s} g^{0.5}(\tan \beta)^{0.4}\left(D_{50}\right)^{-0.6}\left(H_{s, b r}\right)^{3.1} \sin \left(2 \theta_{b r}\right) \text {, }
$$

where $Q_{m}$ is the LST rate; $\tan \beta$ denotes the slope of the beach profile in the surf zone; $K_{\text {swell }}$ represents the swell factor, which measures the effects of swell on the LST rate; $D_{50}$ and $\rho_{s}$ stand for the size and density of the sediment; $g$ is the gravitational acceleration; and $H_{s, b r}$ and $\theta_{b r}$ denote, respectively, the significant wave height and the wave angle with respect to a line normal to the coastline under breaking conditions. The latter parameters were determined through the propagation model for 341 evenly distributed beach profiles (with a spacing of $20 \mathrm{~m}$ between consecutive profiles) along the shoreline between Salobreña Rock and Motril Port (Figure 1).

Changes in LST rates produced by the wave farm with respect the baseline case study were assessed by means of the non-dimensional LST rate reduction $(\tau)$, defined as,

$$
\tau=1-\left(\frac{Q}{Q_{0}}\right)
$$


where $Q_{0}$ and $Q$ are, respectively, the LST rates in the baseline case and the case with wave farm under consideration.

The coastline evolution and the values of dry beach surface for the defined wave conditions (Table 1 and case studies (Figure 3 were quantified through the one-line model, which computes the changes in the shoreline position based on the LST gradients. The model is based on the following equation [76]:

$$
\frac{\partial y_{s}}{\partial t}=\frac{1}{D}\left(-\frac{\partial Q_{t}}{\partial x}\right)
$$

where $y_{s}$ is the shoreline position, $Q_{t}$ is the LST rate (in $\mathrm{m}^{3} / \mathrm{s}$ ) and $D$ is the sum of the height of the berm and the closure depth. The coupled numerical scheme used in this work (SWAN model, LST formulation of [75] and one-line model) was proven in previous work [68, versus field data, to successfully model the variation of the coastline in Playa Granada. In the cases of non-calibrated numerical models, it could be advisable to perform sensitivity analysis to check the uncertainty of the model results depending on the variations in the input parameters, e.g. with Monte Carlo simulations.

To analyse the effects of the inter-WEC spacing with respect to the natural, no-wave farm case study, we used as indicator the non-dimensional shoreline advance $(v)$, defined as,

$$
v=\frac{\Delta y-\Delta y_{0}}{\max \left(\left|\Delta y_{0}\right|\right)}
$$

where $\Delta y_{0}$ and $\Delta y$ represent the displacement of a point on the coastline, respectively in the baseline and the case under consideration.

\section{Results}

\subsection{Wave propagation patterns}

In this section, the impacts caused by the dual WEC array on wave transmission are analysed. The inter-WEC spacing is found to play a relevant part (Figure 4). Under high energy, W waves, a more compact array results in a more pronounced and narrower wake, i.e., smaller wave heights but concentrated near Punta del Santo (Figure 4 a1-a2). When the inter-WEC spacing is larger, the 

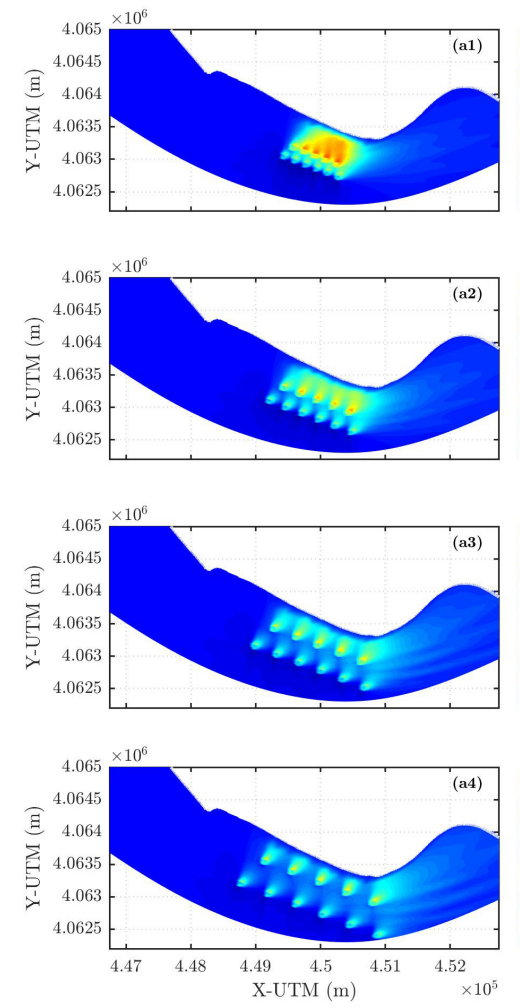
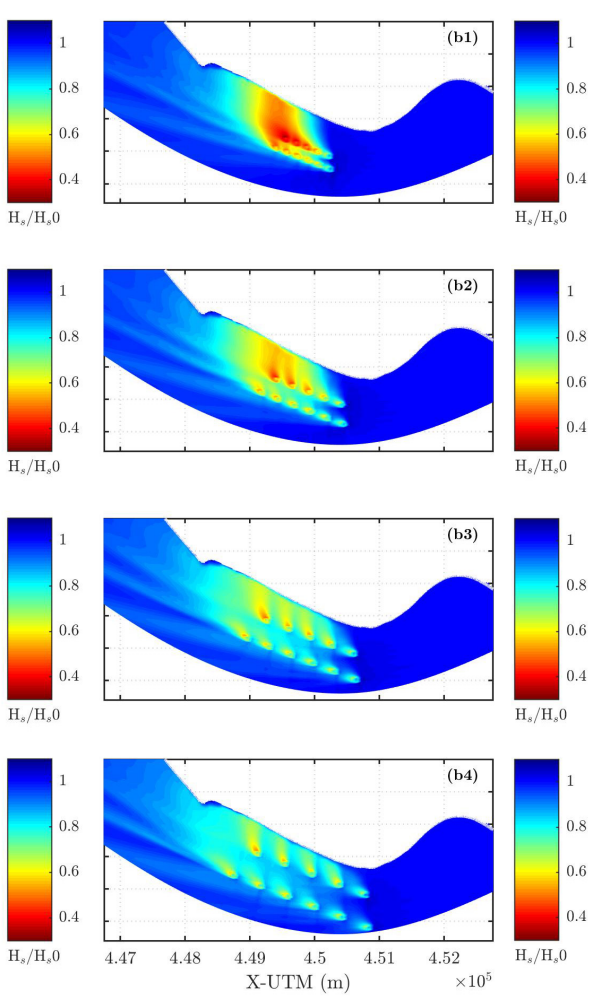

Figure 4: Ratio of the significant wave height in each of the wave farm cases $\left(H_{s}\right)$ to the baseline $\left(H_{s 0}\right)$; from top to bottom, case studies 1 - 4; W (a, left) and $\mathrm{E}$ (b, right) high energy conditions.

Under high energy, E sea states, a similar behaviour is observed, with a higher reduction in wave height for the first two case studies, in particular in the vicinity of the Guadalfeo River mouth (Figure 4 $\mathrm{b} 1-\mathrm{b} 2$ ). The wakes of the individual WECs merge under E waves, resulting in a more pronounced wake (Figure 4p1-b4).

Under $\mathrm{W}$ waves, the greatest reduction is achieved in the east part of the beach, near Punta del Santo, with CS1 producing the highest impact in this zone for both low and high energy conditions (Figure 5 5 2-a3). However, CS2 
to CS4 lead to a more pronounced attenuation mid-beach under low energy conditions.

Considering each case in turn, the overall impact on Playa Granada may be quantified in relative terms (relative to the breaking wave height in the baseline) by means of the alongshore average of the non-dimensional significant wave height reduction, $\eta$ (Table 2). Under $\mathrm{W}$ waves the impact is considerably greater in low energy sea states than in high energy conditions. In low energy conditions, CS2 leads to the greatest wave height reduction, with $\bar{\eta}=18 \%$, whereas CS4 produces the lowest impact $(\bar{\eta}=16 \%)$. Under high energy conditions, $\bar{\eta}$ values are significantly lower, with CS1 leading to the highest reduction $(\bar{\eta}=1.3 \%)$, followed by $\operatorname{CS} 3(\bar{\eta}=1.15 \%)$.
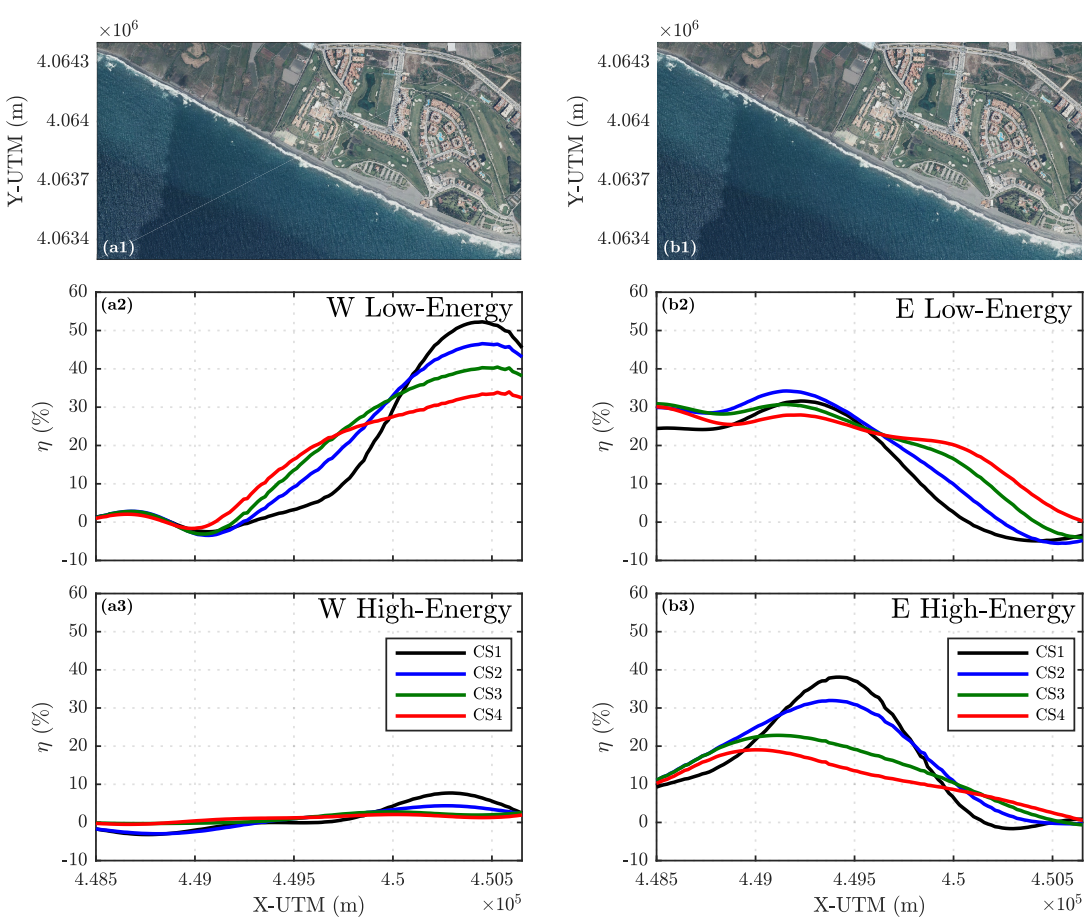

Figure 5: Aerial photograph of Playa Granada (a1-b1). Alongshore variation of the nondimensional significant wave height reduction under W (a) and E (b), low energy (2) and high energy (3) conditions.

By contrast, under $\mathrm{E}$ waves there is little difference in the overall impact be- 
tween the low and high energy conditions. For low energy sea states, a greater attenuation is achieved in the western part of the beach, with the impact decreasing eastwards (Figure 5p2). The highest alongshore-averaged reduction under low energy conditions is induced by $\operatorname{CS} 4(\bar{\eta}=21 \%$, Table 2), since in this case the reduction is extended until Punta del Santo (Figure 502). On the contrary, CS1 leads to the lowest value of the alongshore-averaged reduction $(\bar{\eta}=16 \%)$. Under high energy conditions, the highest impact is produced in the central part of Playa Granada, decreasing both eastwards and westwards (Figure 5b3). The highest alongshore-averaged reduction $(\bar{\eta}=17 \%)$ is obtained for CS2, followed by CS1 $(\bar{\eta}=16 \%)$, whereas CS3 and CS4 produce the lowest impact, with $\bar{\eta}=14 \%$ and $\bar{\eta}=12 \%$, respectively.

Table 2: Longshore average of the non-dimensional significant wave height reduction $(\bar{\eta})$.

\begin{tabular}{ccccc}
\hline & \multicolumn{2}{c}{ Low energy } & \multicolumn{2}{c}{ High energy } \\
& West & East & West & East \\
\hline CS1 & $17 \%$ & $16 \%$ & $\mathbf{1 . 3 \%}$ & $16 \%$ \\
CS2 & $\mathbf{1 8 \%}$ & $19 \%$ & $1 \%$ & $\mathbf{1 7 \%}$ \\
CS3 & $17 \%$ & $20 \%$ & $1.15 \%$ & $14 \%$ \\
CS4 & $16 \%$ & $\mathbf{2 1 \%}$ & $1 \%$ & $12 \%$ \\
\hline
\end{tabular}

\subsection{Longshore sediment transport}

As for the wave height at breaking, under $\mathrm{W}$ waves the wave farm causes LST rates to decline primarily in the vicinity of Punta del Santo (Figure 6a2-a3), in particular under low energy conditions. In fact, under high energy conditions the attenuation in wave heights around the Guadalfeo mouth is negligible (CS3 and CS4) or even negative (CS1 and CS2).

The overall impact of the wave farm on the sediment transport patterns may be quantified by means of the alongshore average of the non-dimensional LST rate reduction $(\tau)$, hereafter denoted by $\bar{\tau}$ (Table 3 ). In low energy conditions, the greatest decline in LST rates $(\bar{\tau}=42 \%)$ occurs in CS3, followed by CS4, CS2 and $\operatorname{CS} 1(\bar{\tau}=33 \%)$. Under $\mathrm{W}$, high energy sea states, the wave farm is less 

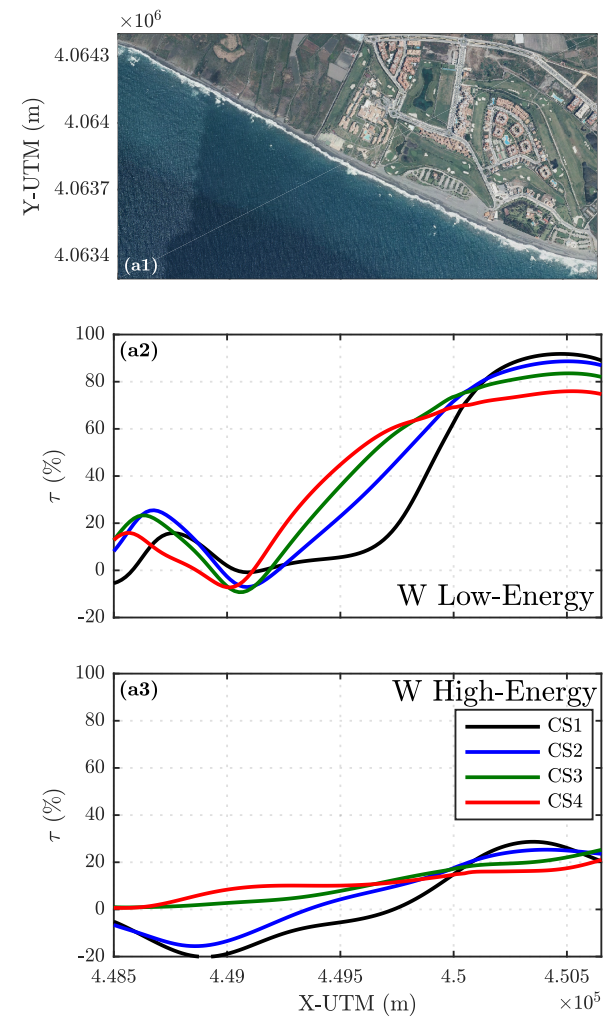
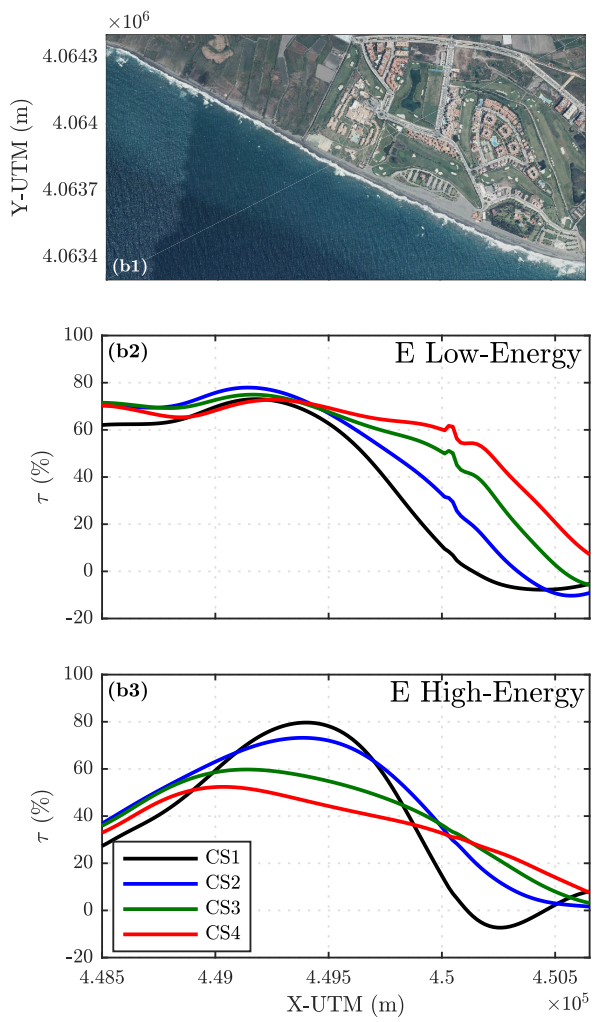

Figure 6: Aerial photograph of Playa Granada (a1-b1). Alongshore variation of the nondimensional LST rate reduction $(\tau)$ under W (a) and E (b), low energy (2) and high energy (3) sea states.

Under E waves, LST rate reduction patterns follow the trends of the significant wave height in the surf zone, with maximum reductions in the west part of the beach, decreasing eastwards in low energy conditions; by contrast, in high energy conditions this most pronounced reduction occurs in the central area of the beach (Figure 6b2-b3). Considering the entire beach, CS4 generates the best overall results under low energy conditions $(\bar{\tau}=59 \%$, Table 3), followed by CS3 $(\bar{\tau}=54 \%), \operatorname{CS} 2(\bar{\tau}=48 \%)$ and $\operatorname{CS} 1(\bar{\tau}=40 \%)$. Under high energy conditions, 
the best case study in terms of coastal protection is CS2 $(\bar{\tau}=45 \%)$, followed by CS3 and CS1, whereas CS4 provides the worst protection $(\bar{\tau}=37 \%)$.

Table 3: Longshore average of the non-dimensional LST rate reduction $(\bar{\tau})$.

\begin{tabular}{ccccc}
\hline & \multicolumn{2}{c}{ Low energy } & \multicolumn{2}{c}{ High energy } \\
& West & East & West & East \\
\hline CS1 & $33 \%$ & $40 \%$ & $2 \%$ & $40 \%$ \\
CS2 & $40 \%$ & $48 \%$ & $5 \%$ & $\mathbf{4 5 \%}$ \\
CS3 & $\mathbf{4 2 \%}$ & $54 \%$ & $10 \%$ & $42 \%$ \\
CS4 & $41 \%$ & $\mathbf{5 9 \%}$ & $\mathbf{1 1 \%}$ & $37 \%$ \\
\hline
\end{tabular}

\subsection{Shoreline position}

In this section, the results concerning the changes in the shoreline position, obtained by means of the LST rates presented in the previous section and the one-line model, are analysed. Accretionary responses with respect to the natural case study dominate under low energy conditions (Figure 7). CS1 and CS2, with a smaller spacing between WECs, lead to the maximum accretion with respect the baseline in the east part of the beach (Figure 721-a2). However, in CS3 and CS4, formed by WECs with a longer spacing between them, the accretion with respect to the natural case study is lower at the east of the beach, but an accretionary response is also observed in the central part of Playa Granada (Figure 733-a4).

The alongshore averages of the non-dimensional shoreline advance $(\bar{v})$ were also computed (Table 4). Results show that under western low energy conditions, CS1 provides the best performance with $\bar{v}=9.6 \%$, followed by CS2 and CS3. Finally, the worst results are obtained with CS4 $(\bar{v}=7.3 \%)$. Under eastern waves, results are similar in the four case studies, with accretion dominating in the westernmost area of Playa Granada and less important changes in the rest of the beach (Figure 7b1-b4). Regarding the alongshore-averaged values, CS3 and CS2 lead to the best performance in terms of coastal protection with 

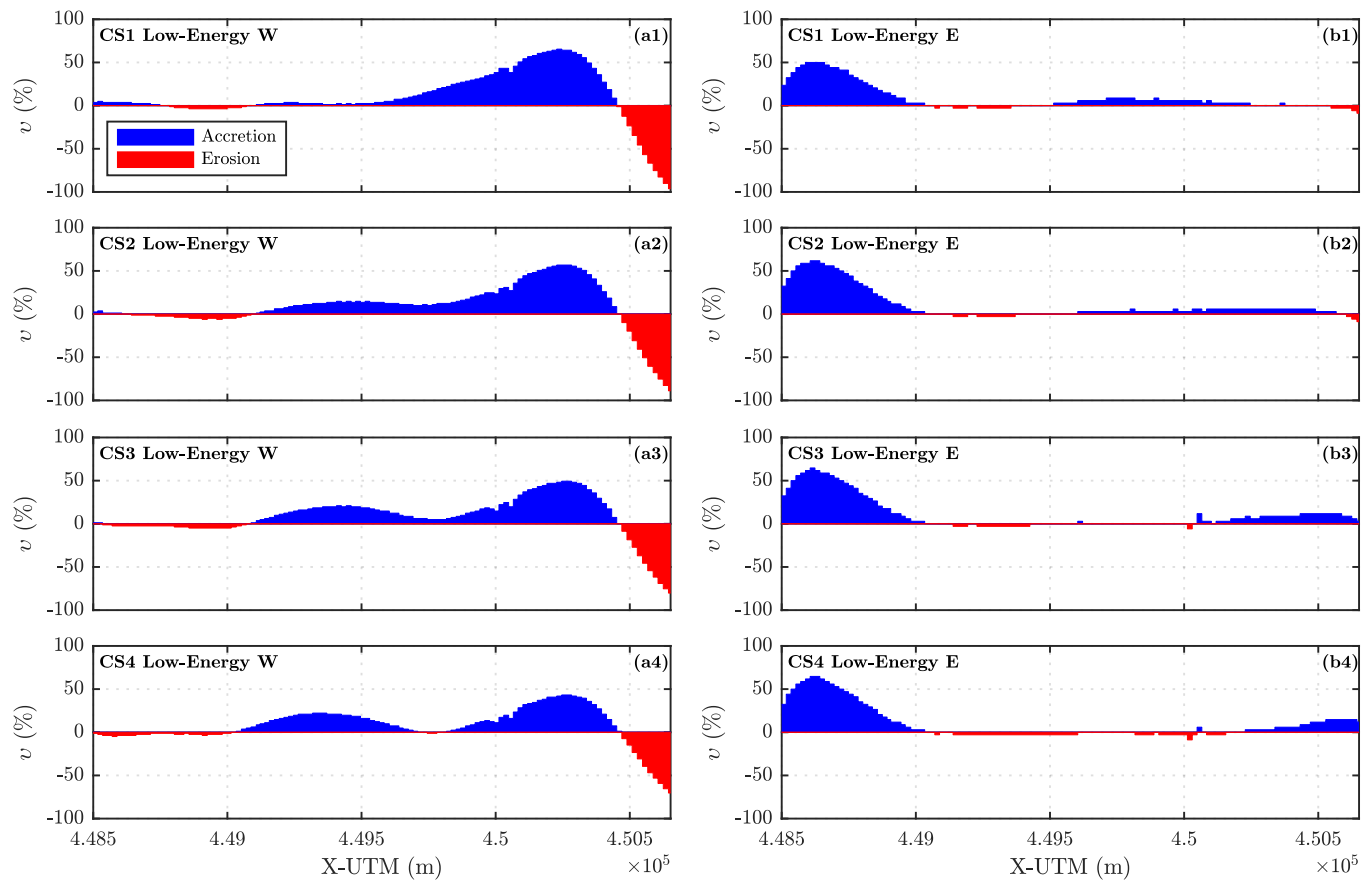

Figure 7: Alongshore variation of the non-dimensional shoreline advance, W (a) and E (b) low energy conditions.

$\bar{v}=10.6 \%$ and $\bar{v}=10.2 \%$, respectively, whereas CS1 and CS4 provide the worst results (Table 4 ).

Non-dimensional shoreline advance values are lower under W, high energy conditions (Figure 8 $81-\mathrm{a} 4$ ). Accretion dominates in mid-beach, with erosion at both the eastern and western boundaries of the beach for CS1 and CS2. In CS3 and CS4, with greater inter-WEC spacings, some accretion occurs also in the E section. The greatest advance occurs in CS2 $(\bar{v}=3.2 \%)$, followed by CS3, whereas in cases CS1 and CS4 the wave farm is slightly less effective (Table 4).

Under E, high energy conditions, in CS1 the wave farm leads to mid-beach accretion and erosion to the east and west (Figure 8b1). In the other case studies, the accretionary zone reaches the east limit of the beach (Punta del Santo). In CS2 and CS3 the greatest alongshore-averaged values are obtained, with $\bar{v}=6.3 \%$ and $\bar{v}=6.0 \%$, respectively (Table 4); conversely, in CS1 the 

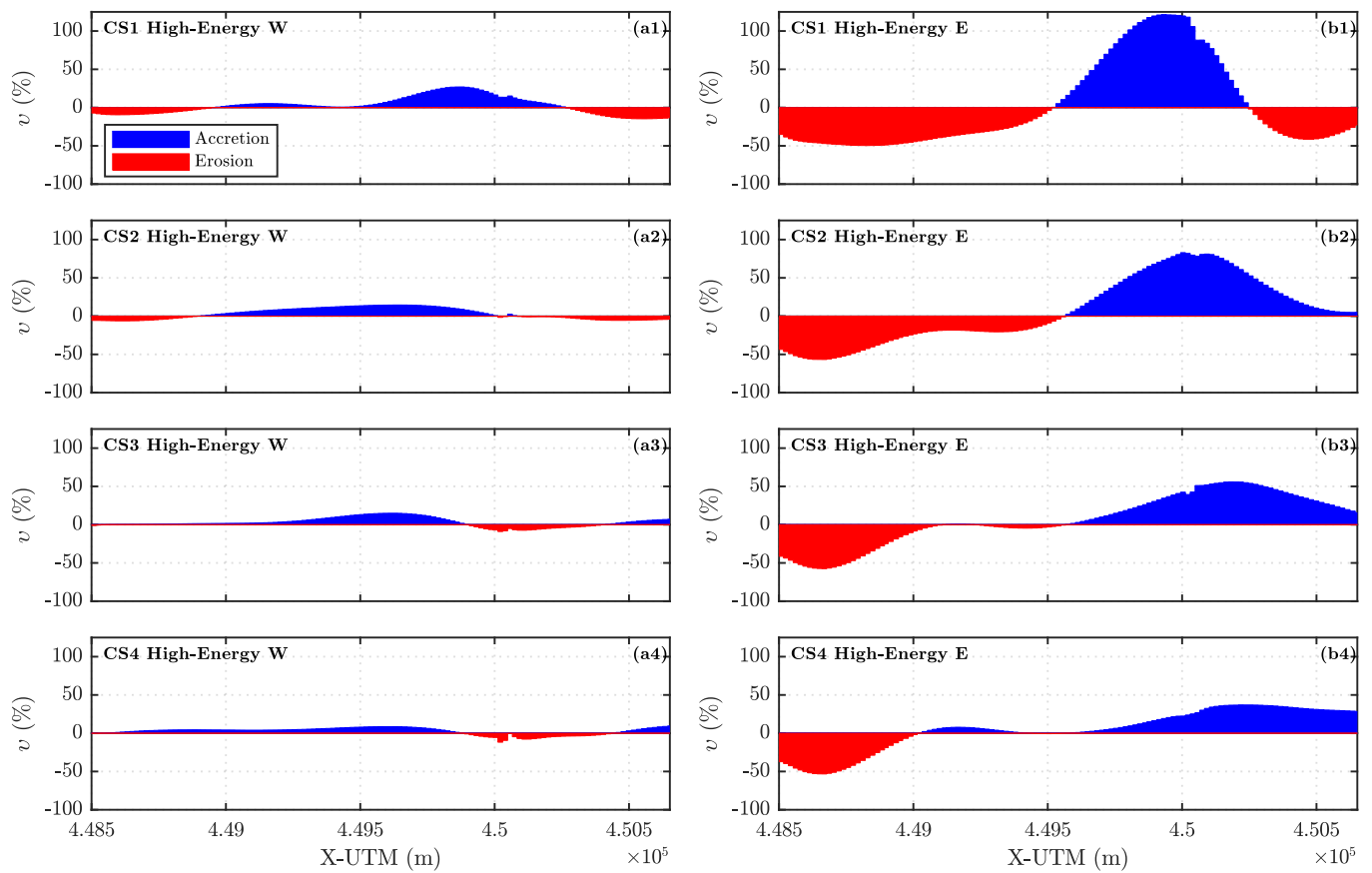

Figure 8: Alongshore variation of the non-dimensional shoreline advance, W (a) and E (b) high energy conditions.

wave farm performance is rather discrete $(\bar{v}=1 \%)$.

\subsection{Dry beach surface}

The shoreline position changes, obtained by means of the one-line model and presented in the previous section, may be used to establish the trends of the dry beach surface respect to the baseline case study (Figure 9), so that positive values of the dry beach surface represent coastal protection induced by the wave farm. Under low energy, W waves, CS1 provides the best results in terms of coastal protection, with an additional surface area of $1.9 \mathrm{~m}^{2}$; at any rate, the protection is of the same order of magnitude in the other cases: CS2 $\left(1.8 \mathrm{~m}^{2}\right)$, CS3 $\left(1.6 \mathrm{~m}^{2}\right)$ and CS4 $\left(1.4 \mathrm{~m}^{2}\right)$. Under low energy, E conditions, the differences are lower and the maximum values - best protection - are obtained for CS2 and CS3. 
Table 4: Longshore average of the non-dimensional shoreline advance $(\bar{v})$.

\begin{tabular}{ccccc} 
& \multicolumn{2}{c}{ Low energy } & \multicolumn{2}{c}{ High energy } \\
& West & East & West & East \\
\hline CS1 & $\mathbf{9 . 6 \%}$ & $8.5 \%$ & $2.5 \%$ & $1 \%$ \\
CS2 & $8.8 \%$ & $10.2 \%$ & $\mathbf{3 . 2 \%}$ & $\mathbf{6 . 3 \%}$ \\
CS3 & $8.0 \%$ & $\mathbf{1 0 . 6 \%}$ & $2.9 \%$ & $6.0 \%$ \\
CS4 & $7.3 \%$ & $9.5 \%$ & $2.4 \%$ & $4.0 \%$ \\
\hline
\end{tabular}

271 As expected, the greatest dry beach area differences are obtained under 272 high energy conditions (Figure 9a2-b2). Under western waves, CS2 provides the ${ }_{273}$ greatest difference $\left(17.4 \mathrm{~m}^{2}\right)$, followed by CS3 $\left(15.9 \mathrm{~m}^{2}\right)$, whereas CS1 and CS4 ${ }_{274}$ lead to the worst results $\left(14.2 \mathrm{~m}^{2}\right.$ and $13.3 \mathrm{~m}^{2}$, respectively). Regarding the 275 high energy, E conditions, CS2 and CS3 induce similar area differences $\left(34.5 \mathrm{~m}^{2}\right.$ 276 and $33.1 \mathrm{~m}^{2}$, respectively), CS4 produces a dry beach surface difference of 22 ${ }_{277} \mathrm{~m}^{2}$ and, finally, the worst results are obtained with CS1 $\left(6.2 \mathrm{~m}^{2}\right)$. 

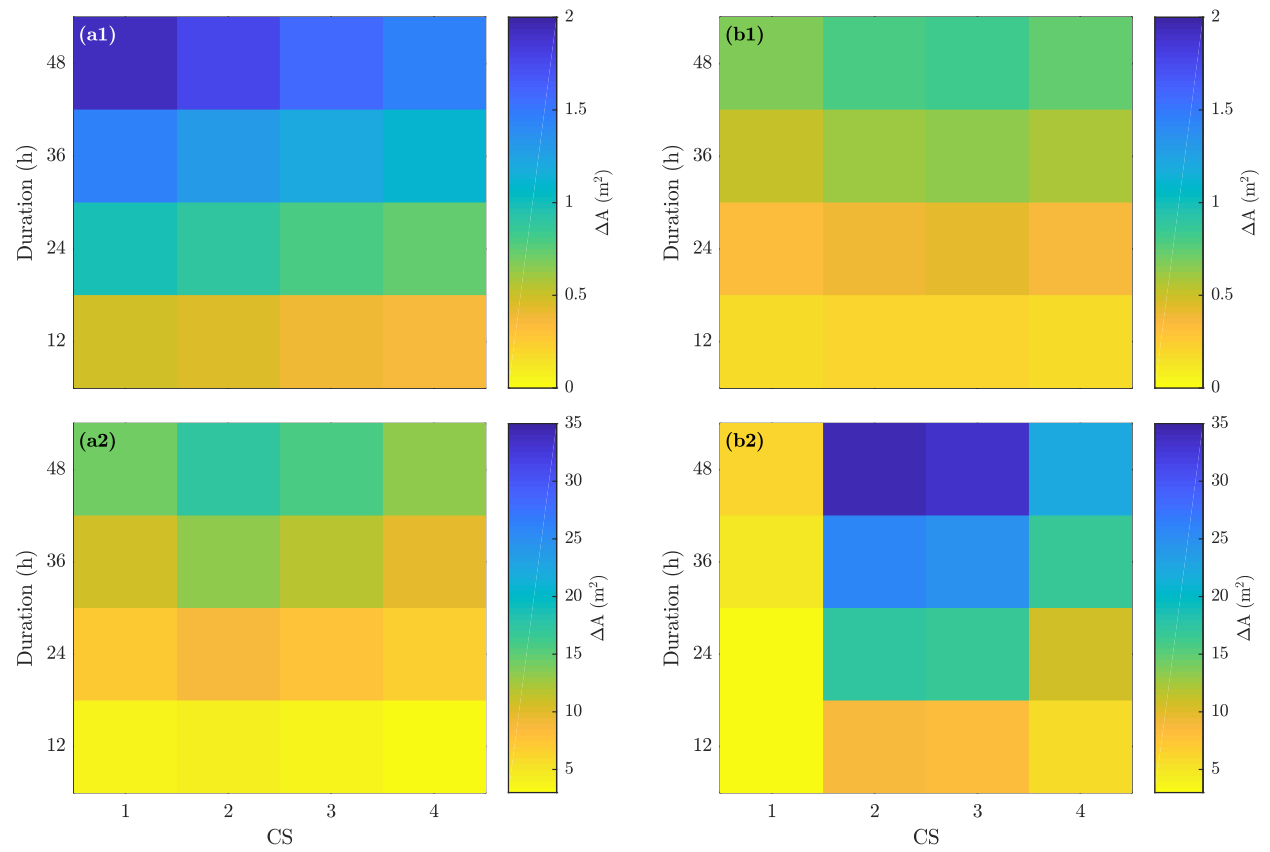

Figure 9: Temporal evolution of the dry beach surface difference between each case study and the baseline for low energy (1), high energy (2), W (a) and E (b) conditions. 


\subsection{Overall performance of the wave farm in the case studies}

On the basis of the previous data, the effectiveness of the dual wave farm depends on the energy content of the sea state (high energy vs. low energy) and, even more importantly, on its mean direction (eastern vs. western). For the purpose of quantifying the coastal protection effectiveness of the farm in the different case studies, in this section the indicators concerned are pondered according to the occurrence of E and W, low energy and high energy conditions, over the last 25 years. This period of time was chosen as representative of the typical life cycle of a wave farm, following 8 , or 80 , among others. The indicators weighted by the occurrence of the respective wave conditions are denoted by the subindex $w\left(\eta_{w}, \tau_{w}, v_{w}, \Delta A_{w}\right)$.

The maximum values of the weighted non-dimensional significant wave height reduction $\left(\eta_{w}\right)$ occur in the central part of the beach for CS1 and CS2 (Figure 10.), and in the west part for CS3 and CS4, with a greater spacing between WECs. In all case studies, the minimum values are observed in the east end of Playa Granada. Alongshore-averaged weighted values show that CS2 and CS1 have the best overall performance, with $\overline{\eta_{w}}=9 \%$ and $\overline{\eta_{w}}=8.9 \%$, respectively. CS3 achieves an alongshore-averaged weighted value of 7.5\%, whereas CS4 leads to the worst performance $\left(\overline{\eta_{w}}=6.3 \%\right)$.

A similar behaviour is obtained for the weighted non-dimensional LST reduction $\left(\tau_{w}\right)$. Again, in cases CS1 and CS2 the largest values occur in the central part of the beach, while in CS3 and CS4 the maxima occur towards the west (Figure 10 d). In this case, CS3 provides the best overall performance with $\overline{\tau_{w}}=26 \%$, followed by $\operatorname{CS} 2$ and $\operatorname{CS} 4\left(\overline{\tau_{w}}=25 \%\right.$ and $\left.\overline{\tau_{w}}=24 \%\right)$. Finally, the lowest alongshore-averaged weighted value is obtained for $\operatorname{CS} 1\left(\overline{\tau_{w}}=21 \%\right)$.

According to the values of the weighted non-dimensional shoreline advance $\left(v_{w}\right)$, in CS1 accretion dominates in the central stretch, whereas erosion prevails in both east and west ends (Figure 10,). In the other cases erosion is limited to the west part of the beach. This erosion zone is narrower in CS3 and CS4, although the maxima of the weighted non-dimensional shoreline advance are lower in these cases than in CS1 and CS2. Alongshore-averaged values show 

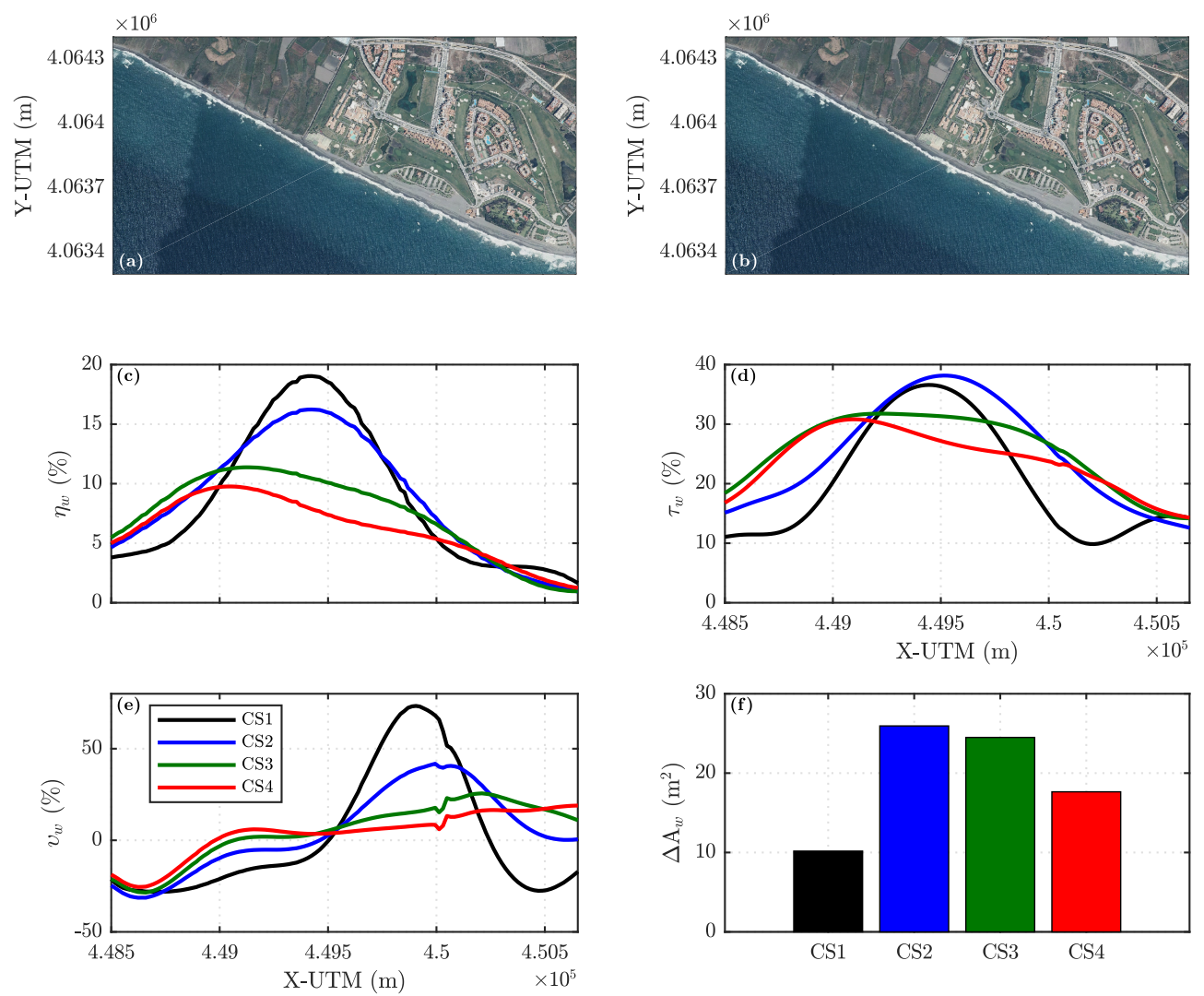

Figure 10: (a,b) Aerial photograph of the beach; (c) $\eta_{w}$ (weighted value of $\eta$ ); (d) $\tau_{w}$ (weighted value of $\tau$ ); (e) $v_{w}$ (weighted value of $v$ ); and (f) $\Delta A_{w}$ (weighted value of $\Delta A$ ) in the four case studies.

that the best performance in terms of increased dry beach area occurs for CS2 $\left(\overline{v_{w}}=4.7 \%\right)$, followed by CS3 $\left(\overline{v_{w}}=4.5 \%\right), \operatorname{CS} 4\left(\overline{v_{w}}=3.3 \%\right)$ and $\operatorname{CS} 1\left(\overline{v_{w}}=\right.$ $1.8 \%)$.

Finally, the overall impact on the dry beach surface of Playa Granada is shown in Figure 10f, where it is observed that accretion with respect to the baseline dominates for all case studies. CS1, with the smallest inter-WEC spacing, yields the worst overall performance, with a dry beach surface increase of a mere $10.2 \mathrm{~m}^{2}$. Conversely, the best results occur in $\operatorname{CS} 2\left(\Delta A_{w}=25.9 \mathrm{~m}^{2}\right)$, followed by CS3 $\left(\Delta A_{w}=24.5 \mathrm{~m}^{2}\right)$. Finally, CS4 shows that when the inter- 
WEC spacing is increased beyond a certain threshold, the coastal protection performance of the wave farm decreases significantly $\left(\Delta A_{w}=17.6 \mathrm{~m}^{2}\right)$.

\section{Discussion}

Wave power is poised to play a fundamental part in the decarbonisation of the energy mix. For wave energy to be produced in sufficient quantity, WECs will be deployed in wave farms. Along with the research focused on developing new WECs and improving the performance of existing devices, the effects of wave farms on the shoreline must be investigated. These effects may be used in coastal areas subjected to erosion to alleviate this problem; in other words, wave farms may have a dual function: carbon-free power production and coastal erosion control.

Recent research on the impacts of a wave farm on the coastline has focused on the general layout of the farm [78] and its position alongshore [79. There was a knowledge gap in relation to one of the fundamental design variables of a wave farm, the inter-device spacing, and in particular to the manner in which the effects of the farm on the coastline are conditioned by it - and therein lies the motivation of this work.

In other words, the focus of this work was the manner in which the capability for coastal erosion control of a dual wave farm depends on the spacing between its WECs, in particular in the case of a gravel-dominated beach. With this purpose, modifications in wave propagation between the baseline and four case studies with different inter-WEC spacings were determined using the SWAN wave propagation model. The case studies analysed do not cover the full range of possibilities, and this research should be continued to explore more values of inter-device spacing.

Another aspect of note is the characteristics of the beach itself. Playa Granada is a gravel-dominated beach, and the results of this work cannot be extrapolated to beaches with different sedimentologies. Along the same S Mediterranean coast of Spain are examples of sandy beaches which could be selected 
for this purpose.

\section{Conclusions}

For wave energy to become a fully-fledged renewable, the current understanding of the environmental effects of wave farms, i.e., arrays of wave energy converters, needs to be enhanced. In this context, this work dealt with the question of how the inter-device spacing affects the evolution of the coast in the lee of the wave farm.

A number of case studies with different inter-device spacings were considered. The interaction of the wave field with the farm, its propagation to the coast and its effects on the coastline were modelled using state-of-the-art tools. Based on these results, longshore sediment transport rates were determined and the one-line was applied to determine shoreline evolution. Finally, ad hoc nondimensional indicators of the performance of the dual wave farm for coastal erosion control were applied.

The sea state was found to affect the performance of the dual wave farm. In the case of $\mathrm{W}$ waves, a smaller inter-WEC spacing results in a more pronounced wake of the farm and, consequently, a more pronounced reduction in the significant wave heights in the surf zone and the LST rates. Conversely, a greater spacing reduces the impact of the farm on the shoreline.

In the case of $\mathrm{E}$ waves, and due to the position of the wave farm vis-àvis the beach, the effect of the farm on the beach is more intense, whether it be in terms of significant wave heights in the surf zone or LST rates. The differences between case studies, less marked than under $\mathrm{W}$ waves, are as follows. A smaller inter-WEC spacing leads to accretion in a narrow stretch and erosion elsewhere. With greater inter-WEC spacings, this erosion is mitigated, but the concentrated accretion is also weaker.

The values of the increase in dry beach area $\left(\Delta A_{w}\right)$ show that the best performance is achieved with intermediate inter-WEC spacings, i.e., $2 D$ and $3 D$ (corresponding to case studies CS2 and CS3, respectively). Indeed, these 
case studies lead to the greater increases in weighted dry beach surface $\left(\Delta A_{w}=\right.$ $25.9 \mathrm{~m}^{2}$ and $\Delta A_{w}=24.5 \mathrm{~m}^{2}$, respectively). CS1, with the smallest interWEC spacing $(D)$, results in accretion concentrating in a narrow stretch, with significant erosion elsewhere. Finally, CS4, at the other extreme of inter-WEC spacing $(4 D)$, results in weaker accretion and, overall, a weaker gain in dry beach surface than CS2 and CS3. Based on these results, CS2 (inter-WEC spacing, $2 D=180 \mathrm{~m}$ ) emerges as the best option in terms of coastal protection among those studied in this work.

The methodology proposed here, coupling a wave propagation model with a longshore sediment transport formulation and a shoreline model, can be used as an optimization tool for the application of dual wave farms to coastal erosion control.

Finally, dual wave farms, i.e. wave farms that fulfill the functions of energy production and coastal protection, may be expected to contribute to: the progress of wave power, by increasing its viability through savings in conventional coastal protection measures, e.g., detached breakwaters, groynes, beach nourishments; and thus, more generally, to the decarbonisation of the energy $\operatorname{mix}$.

\section{Acknowledgements}

This research was carried out in the framework of the grants: WAVEIMPACT (PCIG-13-GA-2013-618556, European Commission, Marie Curie fellowship, fellow G. Iglesias) and ICE (Intelligent Community Energy, European Commision, Contract no. 5025), and within the research groups Coastal, Ocean and Sediment Transport (COaST) Engineering Research Group (University of Plymouth, UK) and TEP-209 (University of Granada, Spain). The work of the second author was partly funded by the University of Granada (Programa Contratos Puente 2017). We thank three anonymous reviewers for their improvements to this paper. 


\section{References}

[1] J. Huenteler, C. Niebuhr, T. S. Schmidt, The effect of local and global learning on the cost of renewable energy in developing countries, Journal of Cleaner Production 128 (2016) 6 - 21.

[2] C. Kung, L. Zhang, M. Chang, Promotion policies for renewable energy and their effects in taiwan, Journal of Cleaner Production 142 (2017) 965 -975 .

[3] European Commission, A European Strategic Energy Technology Plan (Set-Plan): Towards a low carbon future, Brussels: Commission of the European Communities (2007).

[4] A. M. Cornett, A global wave energy resource assessment, in: The Eighteenth International Offshore and Polar Engineering Conference, International Society of Offshore and Polar Engineers, 2008.

[5] A. Clément, P. McCullen, A. F. de O. Falcão, A. Fiorentino, F. Gardner, K. Hammarlund, G. Lemonis, T. Lewis, K. Nielsen, S. Petroncini, M.-T. Pontes, P. Schild, B.-O. Sjöström, H. C. Sørensen, T. Thorpe, Wave energy in Europe: current status and perspectives, Renewable and Sustainable Energy Reviews 6 (2002) 405-431.

[6] I. Lpez, B. Pereiras, F. Castro, G. Iglesias, Holistic performance analysis and turbine-induced damping for an owc wave energy converter, Renewable Energy 85 (2016) 1155 - 1163.

[7] A. F. de O. Falcão, Modelling and control of oscillating-body wave energy converters with hydraulic power take-off and gas accumulator, Ocean Engineering 34 (2007) 2021-2032.

[8] L. Margheritini, D. Vicinanza, P. Frigaard, SSG wave energy converter: Design, reliability and hydraulic performance of an innovative overtopping device, Renewable Energy 34 (2009) 1371-1380. 
[9] H. Fernandez, G. Iglesias, R. Carballo, A. Castro, J. Fraguela, F. TaveiraPinto, M. Sanchez, The new wave energy converter WaveCat: Concept and laboratory tests, Marine Structures 29 (2012) 58-70.

[10] I. López, B. Pereiras, F. Castro, G. Iglesias, Optimisation of turbineinduced damping for an OWC wave energy converter using a RANS-VOF numerical model, Applied Energy 127 (2014) 105 - 114.

[11] I. López, G. Iglesias, Efficiency of OWC wave energy converters: A virtual laboratory, Applied Ocean Research 44 (2014) 63 - 70.

[12] I. López, B. Pereiras, F. Castro, G. Iglesias, Performance of OWC wave energy converters: Influence of turbine damping and tidal variability, International Journal of Energy Research 39 (2015) 472-483. ER-13-4164.R2.

[13] I. López, A. Castro, G. Iglesias, Hydrodynamic performance of an oscillating water column wave energy converter by means of particle imaging velocimetry, Energy 83 (2015) 89 - 103.

[14] G. Iglesias, R. Carballo, Choosing the site for the first wave farm in a region: A case study in the Galician Southwest (Spain), Energy 36 (2011) $5525-5531$.

[15] L. Liberti, A. Carillo, G. Sannino, Wave energy resource assessment in the Mediterranean, the Italian perspective, Renewable Energy 50 (2013) 938-949.

[16] G. Zodiatis, G. Galanis, A. Nikolaidis, C. Kalogeri, D. Hayes, G. C. Georgiou, P. C. Chu, G. Kallos, Wave energy potential in the Eastern Mediterranean Levantine Basin. An integrated 10-year study, Renewable Energy 69 (2014) 311-323.

[17] F. Arena, V. Laface, G. Malara, A. Romolo, A. Viviano, V. Fiamma, G. Sannino, A. Carillo, Wave climate analysis for the design of wave energy harvesters in the Mediterranean Sea, Renewable Energy 77 (2015) 125-141. 
[18] R. Carballo, M. Sánchez, V. Ramos, J. Fraguela, G. Iglesias, The intraannual variability in the performance of wave energy converters: A comparative study in N Galicia (Spain), Energy 82 (2015) 138 - 146.

[19] M. López, M. Veigas, G. Iglesias, On the wave energy resource of Peru, Energy Conversion and Management 90 (2015) $34-40$.

[20] D. Silva, A. R. Bento, P. Martinho, C. G. Soares, High resolution local wave energy modelling in the Iberian Peninsula, Energy 91 (2015) 1099-1112.

[21] G. Besio, L. Mentaschi, A. Mazzino, Wave energy resource assessment in the mediterranean sea on the basis of a 35-year hindcast, Energy 94 (2016) $50-63$.

[22] A. Viviano, S. Naty, E. Foti, T. Bruce, W. Allsop, D. Vicinanza, Largescale experiments on the behaviour of a generalised oscillating water column under random waves, Renewable Energy 99 (2016) 875 - 887.

[23] E. Medina-López, R. Bergillos, A. Moñino, M. Clavero, M. Ortega-Sánchez, Effects of seabed morphology on oscillating water column wave energy converters, Energy 135 (2017) 659-673.

[24] S. Bozzi, G. Besio, G. Passoni, Wave power technologies for the mediterranean offshore: Scaling and performance analysis, Coastal Engineering 136 (2018) $130-146$.

[25] A. López-Ruiz, R. J. Bergillos, J. M. Raffo-Caballero, M. Ortega-Sánchez, Towards an optimum design of wave energy converter arrays through an integrated approach of life cycle performance and operational capacity, Applied Energy 209 (2018) $20-32$.

[26] A. López-Ruiz, R. J. Bergillos, A. Lira-Loarca, M. Ortega-Sánchez, A methodology for the long-term simulation and uncertainty analysis of the operational lifetime performance of wave energy converter arrays, Energy 153 (2018) 126-135. 
[27] A. Moñino, E. Medina-López, R. J. Bergillos, M. Clavero, A. Borthwick, M. Ortega-Sánchez, Thermodynamics and Morphodynamics in Wave Energy, Springer, 2018.

[28] M. Veigas, G. Iglesias, Potentials of a hybrid offshore farm for the island of Fuerteventura, Energy Conversion and Management 86 (2014) 300 - 308.

[29] R. Carballo, M. Sánchez, V. Ramos, F. Taveira-Pinto, G. Iglesias, A high resolution geospatial database for wave energy exploitation, Energy 68 (2014) $572-583$.

[30] C. Iuppa, L. Cavallaro, E. Foti, D. Vicinanza, Potential wave energy production by different wave energy converters around Sicily, Journal of Renewable and Sustainable Energy 7 (2015) 061701.

[31] A. López-Ruiz, R. J. Bergillos, M. Ortega-Sánchez, The importance of wave climate forecasting on the decision-making process for nearshore wave energy exploitation, Applied Energy 182 (2016) 191 - 203.

[32] S. Astariz, G. Iglesias, The economics of wave energy: A review, Renewable and Sustainable Energy Reviews 45 (2015) 397 - 408.

[33] S. Astariz, A. Vazquez, G. Iglesias, Evaluation and comparison of the levelized cost of tidal, wave, and offshore wind energy, Journal of Renewable and Sustainable Energy 7 (2015) 053112.

[34] S. Astariz, G. Iglesias, Wave energy vs. other energy sources: A reassessment of the economics, International Journal of Green Energy 13 (2016) $747-755$.

[35] P. Contestabile, E. Di Lauro, M. Buccino, D. Vicinanza, Economic Assessment of Overtopping BReakwater for Energy Conversion (OBREC): A Case Study in Western Australia, Sustainability 9 (2017).

[36] S. Astariz, C. Perez-Collazo, J. Abanades, G. Iglesias, Towards the optimal design of a co-located wind-wave farm, Energy 84 (2015) $15-24$. 
[37] S. Astariz, G. Iglesias, Enhancing wave energy competitiveness through co-located wind and wave energy farms. a review on the shadow effect, Energies 8 (2015) 7344-7366.

[38] S. Astariz, J. Abanades, C. Perez-Collazo, G. Iglesias, Improving wind farm accessibility for operation and maintenance through a co-located wave farm: Influence of layout and wave climate, Energy Conversion and Management 95 (2015) $229-241$.

[39] S. Astariz, G. Iglesias, Output power smoothing and reduced downtime period by combined wind and wave energy farms, Energy 97 (2016) 69 81.

[40] C. Pérez-Collazo, D. Greaves, G. Iglesias, A review of combined wave and offshore wind energy, Renewable and Sustainable Energy Reviews 42 (2015) $141-153$.

[41] D. Millar, H. Smith, D. Reeve, Modelling analysis of the sensitivity of shoreline change to a wave farm, Ocean Engineering 34 (2007) 884-901.

[42] M. Veigas, V. Ramos, G. Iglesias, A wave farm for an island: Detailed effects on the nearshore wave climate, Energy 69 (2014) $801-812$.

[43] J. Abanades, D. Greaves, G. Iglesias, Coastal defence using wave farms: The role of farm-to-coast distance, Renewable Energy 75 (2015) 572-582.

[44] J. Abanades, D. Greaves, G. Iglesias, Coastal defence through wave farms, Coastal Engineering 91 (2014) 299-307.

[45] R. J. Bergillos, A. López-Ruiz, E. Medina-López, A. Moñino, M. OrtegaSánchez, The role of wave energy converter farms on coastal protection in eroding deltas, Guadalfeo, southern Spain, Journal of Cleaner Production $171(2018) 356-367$.

[46] J. Abanades, G. Flor-Blanco, G. Flor, G. Iglesias, Dual wave farms for energy production and coastal protection, Ocean \& Coastal Management $160(2018) 18-29$. 
[47] J. P. M. Syvitski, A. J. Kettner, I. Overeem, E. W. H. Hutton, M. T. Hannon, G. R. Brakenridge, J. Day, C. Vörösmarty, Y. Saito, L. Giosan, R. J. Nicholls, Sinking deltas due to human activities, Nature Geoscience 2 (2009) 681-686.

[48] E. J. Anthony, N. Marriner, C. Morhange, Human influence and the changing geomorphology of Mediterranean deltas and coasts over the last 6000 years: From progradation to destruction phase?, Earth-Science Reviews 139 (2014) 336-361.

[49] S. Brown, R. Nicholls, Subsidence and human influences in mega deltas: The case of the Ganges-Brahmaputra-Meghna, Science of The Total Environment 527-528 (2015) $362-374$.

[50] L. Aragonés, J. Pagán, M. López, J. García-Barba, The impacts of Segura River (Spain) channelization on the coastal seabed, Science of The Total Environment 543 (2016) 493 - 504.

[51] J. Pagán, I. López, L. Aragonés, J. Garcia-Barba, The effects of the anthropic actions on the sandy beaches of Guardamar del Segura, Spain, Science of The Total Environment 601-602 (2017) 1364 - 1377.

[52] R. J. Bergillos, A. López-Ruiz, D. Principal-Gómez, M. Ortega-Sánchez, An integrated methodology to forecast the efficiency of nourishment strategies in eroding deltas, Science of The Total Environment 613-614 (2018) 1175 -1184 .

[53] A. Payo, A. Mukhopadhyay, S. Hazra, T. Ghosh, S. Ghosh, S. Brown, R. J. Nicholls, L. Bricheno, J. Wolf, S. Kay, A. N. Lázár, A. Haque, Projected changes in area of the Sundarban mangrove forest in Bangladesh due to SLR by 2100, Climatic Change 139 (2016) 279-291.

[54] A. Sánchez-Arcilla, M. García-León, V. Gracia, R. Devoy, A. Stanica, J. Gault, Managing coastal environments under climate change: Path- 
ways to adaptation, Science of The Total Environment 572 (2016) 1336 1352.

[55] T. Spencer, M. Schuerch, R. J. Nicholls, J. Hinkel, D. Lincke, A. T. Vafeidis, R. Reef, L. McFadden, S. Brown, Global coastal wetland change under sealevel rise and related stresses: the DIVA Wetland Change Model, Global and Planetary Change 139 (2016) 15-30.

[56] C. Vidal, J. Méndez Fernando, G. Díaz, R. Legaz, Impact of Santoña WEC installation on the littoral processes, in: Proceedings of the 7th European wave and tidal energy conference, Porto, Portugal, 2007, pp. 11-14.

[57] A. Palha, L. Mendes, C. J. Fortes, A. Brito-Melo, A. Sarmento, The impact of wave energy farms in the shoreline wave climate: Portuguese pilot zone case study using Pelamis energy wave devices, Renewable Energy 35 (2010) $62-77$.

[58] R. Carballo, G. Iglesias, Wave farm impact based on realistic wave-WEC interaction, Energy 51 (2013) 216-229.

[59] J. Abanades, D. Greaves, G. Iglesias, Wave farm impact on the beach profile: A case study, Coastal Engineering 86 (2014) 36-44.

[60] J. Abanades, D. Greaves, G. Iglesias, Wave farm impact on beach modal state, Marine Geology 361 (2015) 126-135.

[61] R. J. Bergillos, C. Rodríguez-Delgado, A. López-Ruiz, A. Millares, M. Ortega-Sánchez, M. A. Losada, Recent human-induced coastal changes in the Guadalfeo river deltaic system (southern Spain), in: Proceedings of the 36th IAHR-International Association for Hydro-Environment Engineering and Research World Congress: http://89.31.100.18/ iahrpapers/87178.pdf, 2015.

[62] A. Millares, M. J. Polo, A. Moñino, J. Herrero, M. A. Losada, Bedload dynamics and associated snowmelt influence in mountainous and semiarid alluvial rivers, Geomorphology 206 (2014) 330-342. 
[63] M. A. Losada, A. Baquerizo, M. Ortega-Sánchez, A. Ávila, Coastal evolution, sea level, and assessment of intrinsic uncertainty, Journal of Coastal Research 59 (2011) 218-228.

[64] R. J. Bergillos, C. Rodríguez-Delgado, A. Millares, M. Ortega-Sánchez, M. A. Losada, Impact of river regulation on a Mediterranean delta: Assessment of managed versus unmanaged scenarios, Water Resources Research 52 (2016) 5132-5148.

[65] G. Hoffmann, Holozänstratigraphie und Küstenlinienverlagerung an der andalusischen Mittelmeerküste, Ph.D. thesis, Universität Bremen, 1987.

[66] A. Jabaloy-Sánchez, F. J. Lobo, A. Azor, W. Martín-Rosales, J. V. PérezPeña, P. Bárcenas, J. Macías, L. M. Fernández-Salas, M. Vázquez-Vílchez, Six thousand years of coastline evolution in the Guadalfeo deltaic system (southern Iberian Peninsula), Geomorphology 206 (2014) 374-391.

[67] A. Félix, A. Baquerizo, J. M. Santiago, M. A. Losada, Coastal zone management with stochastic multi-criteria analysis, Journal of Environmental Management 112 (2012) 252-266.

[68] R. J. Bergillos, C. Rodríguez-Delgado, M. Ortega-Sánchez, Advances in management tools for modeling artificial nourishments in mixed beaches, Journal of Marine Systems 172 (2017) 1-13.

[69] M. Ortega-Sánchez, R. J. Bergillos, A. López-Ruiz, M. A. Losada, Morphodynamics of Mediterranean Mixed Sand and Gravel Coasts, Springer, 2017.

[70] M. Ortega-Sánchez, M. A. Losada, A. Baquerizo, On the development of large-scale cuspate features on a semi-reflective beach: Carchuna beach, Southern Spain, Marine Geology 198 (2003) 209-223.

[71] R. J. Bergillos, G. Masselink, M. Ortega-Sánchez, Coupling cross-shore and longshore sediment transport to model storm response along a mixed 
sand-gravel coast under varying wave directions., Coastal Engineering, 129 (2017) 93-104.

[72] R. J. Bergillos, A. López-Ruiz, M. Ortega-Sánchez, G. Masselink, M. A. Losada, Implications of delta retreat on wave propagation and longshore sediment transport-Guadalfeo case study (southern Spain), Marine Geology 382 (2016) 1-16.

[73] R. J. Bergillos, M. Ortega-Sánchez, G. Masselink, M. A. Losada, Morphosedimentary dynamics of a micro-tidal mixed sand and gravel beach, Playa Granada, southern Spain, Marine Geology 379 (2016) 28-38.

[74] L. Holthuijsen, N. Booij, R. Ris, A spectral wave model for the coastal zone, ASCE, 1993.

[75] L. C. van Rijn, A simple general expression for longshore transport of sand, gravel and shingle, Coastal Engineering 90 (2014) 23 - 39.

[76] R. Pelnard-Considère, Essai de theorie de l'evolution des formes de rivage en plages de sable et de galets, Les Energies de la Mer: Compte Rendu Des Quatriemes Journees de L'hydraulique, Paris 13, 14 and 15 Juin 1956; Question III, rapport 1, 74-1-10 (1956).

[77] G. Iglesias, R. Carballo, A. Castro, B. Fraga, Development and design of the WaveCat ${ }^{\mathrm{TM}}$ energy converter, in: Coastal Engineering 2008: (In 5 Volumes), World Scientific, 2009, pp. 3970-3982.

[78] C. Rodriguez-Delgado, R. J. Bergillos, M. Ortega-Sánchez, G. Iglesias, Protection of gravel-dominated coasts through wave farms: Layout and shoreline evolution, Science of The Total Environment 636 (2018) 1541-1552.

[79] C. Rodriguez-Delgado, R. J. Bergillos, M. Ortega-Sánchez, G. Iglesias, Wave farm effects on the coast: The alongshore position, Science of The Total Environment 640 (2018) 1176-1186. 
${ }_{648}$ [80] R. Alonso, S. Solari, L. Teixeira, Wave energy resource assessment in Uruguay, Energy 93 (2015) $683-696$. 
Click here to download high resolution image

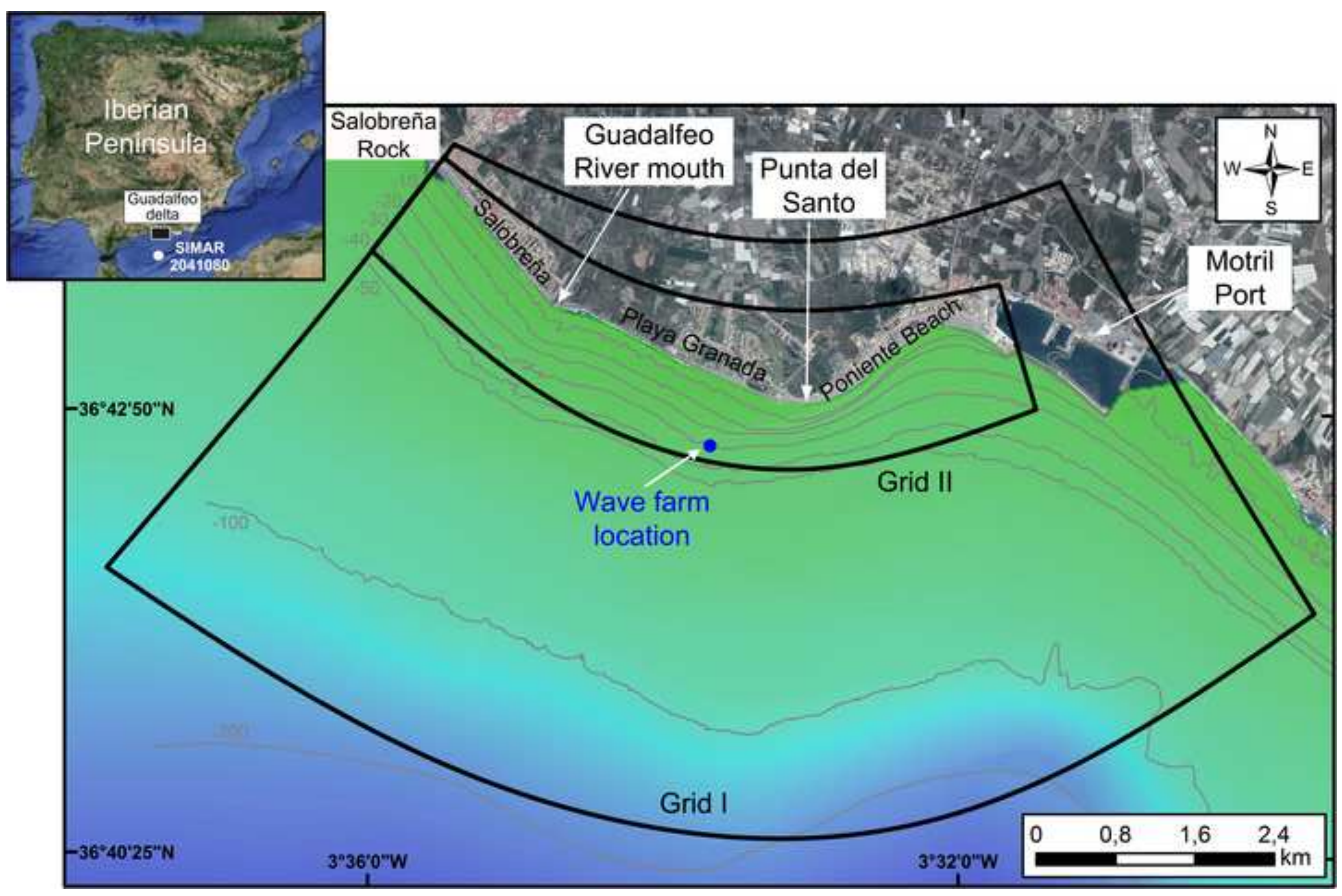


Click here to download high resolution image

(a)

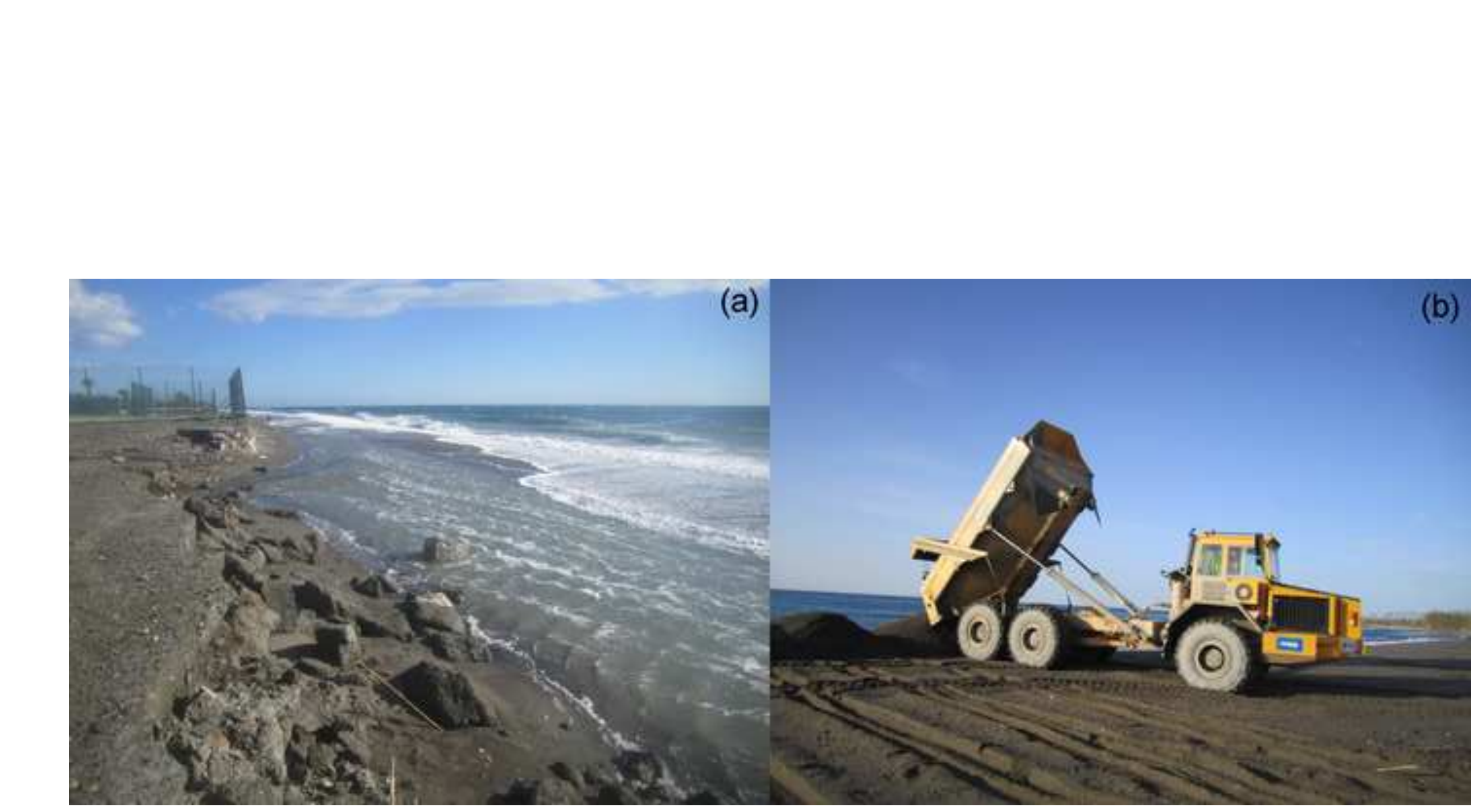




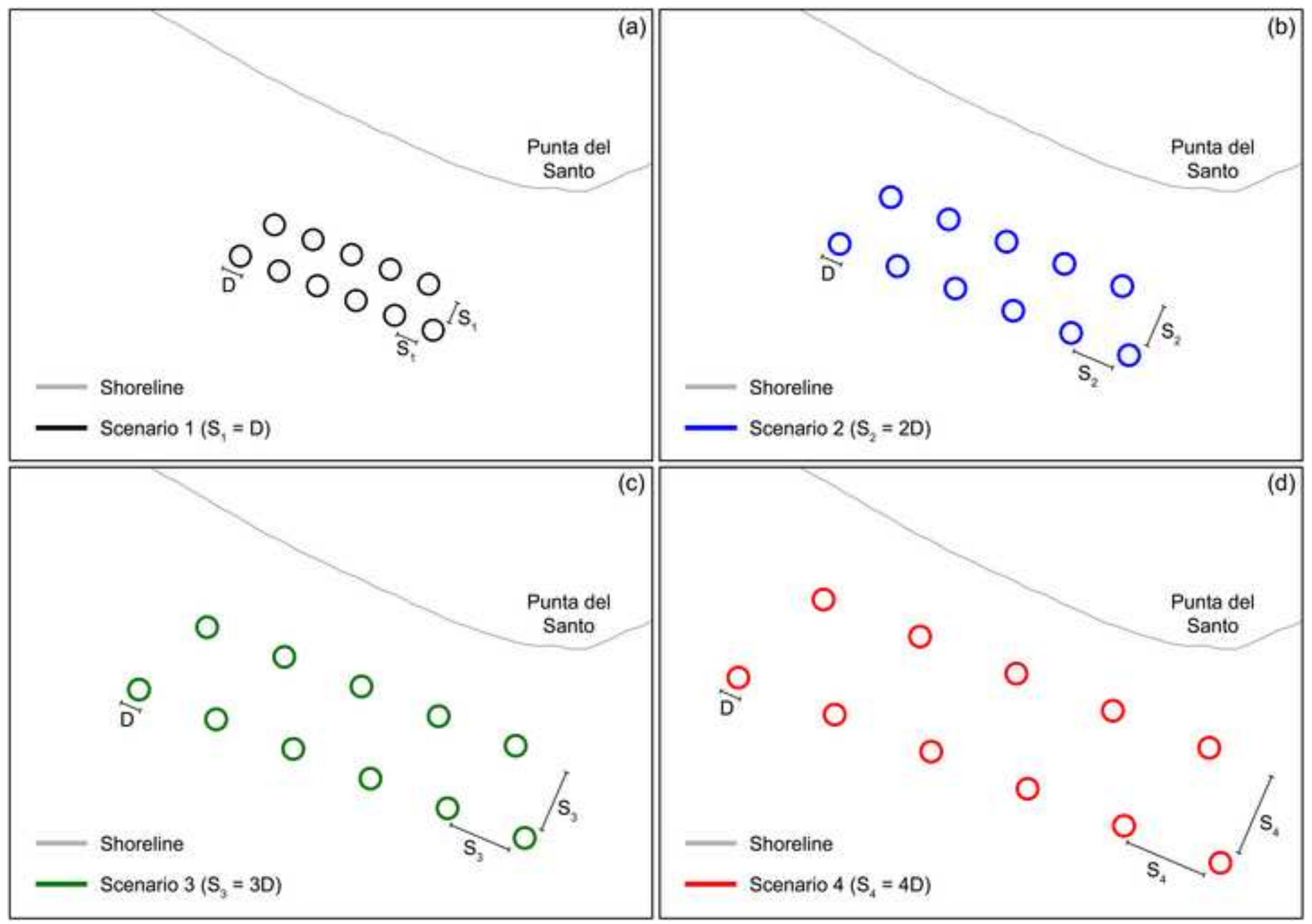


Click here to download high resolution image
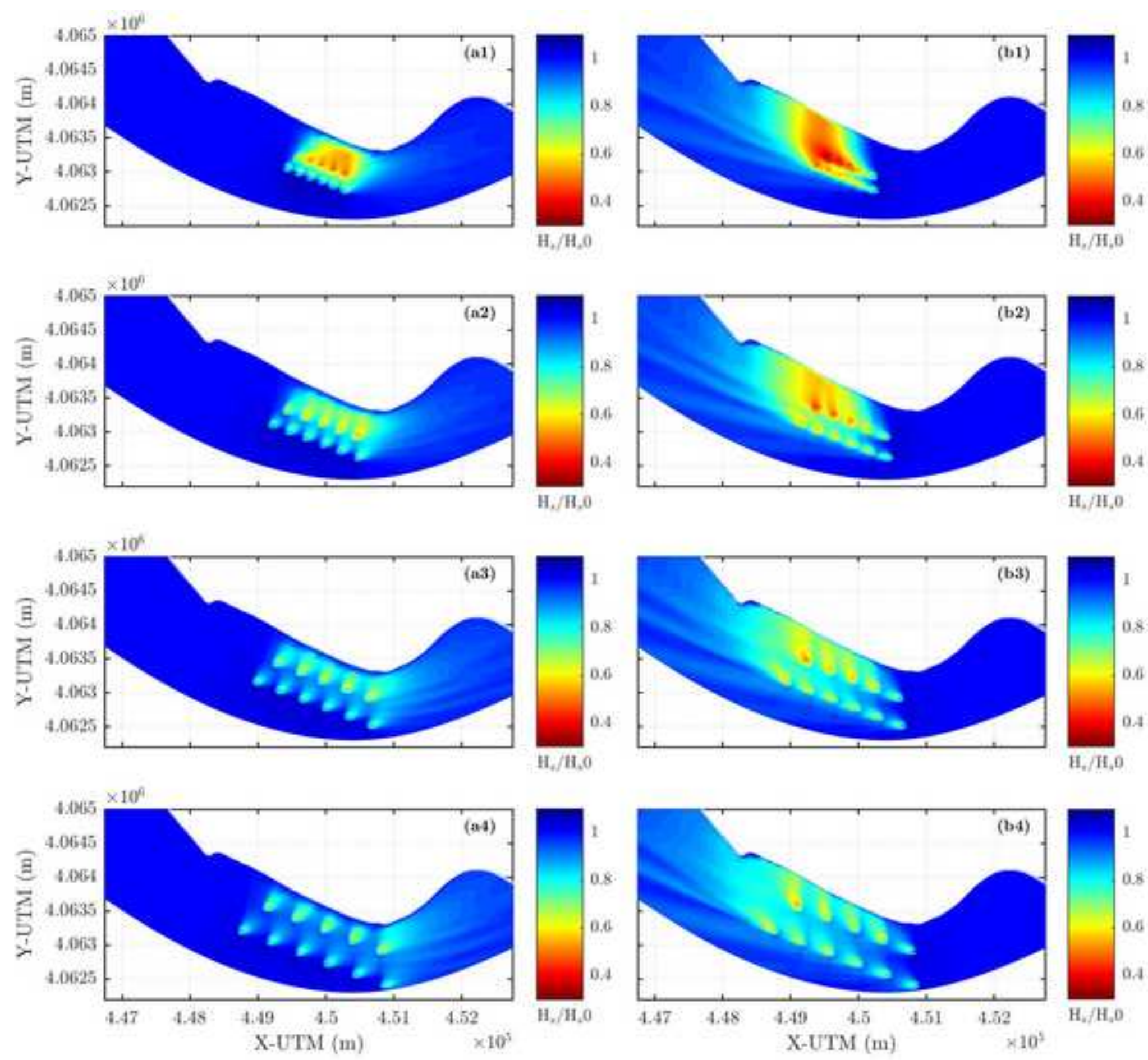


\section{Figure $5^{10^{6}}$}
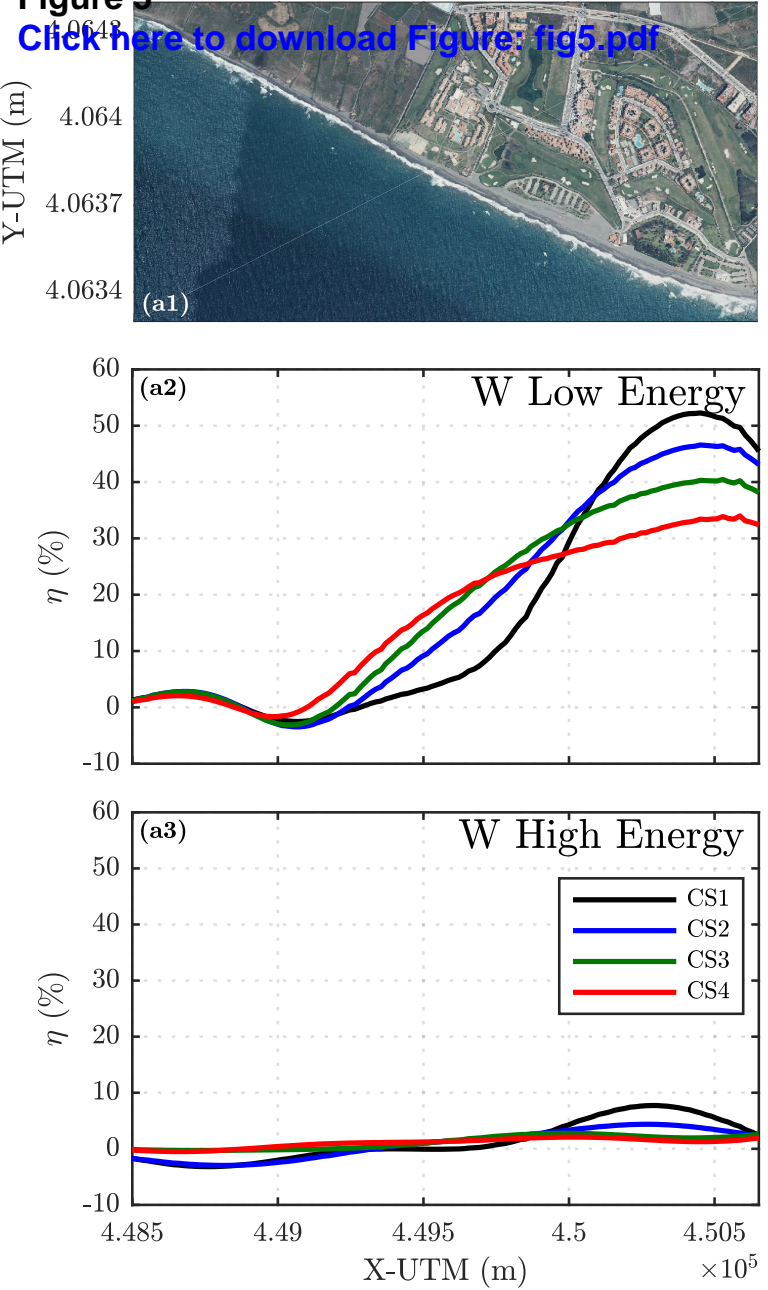
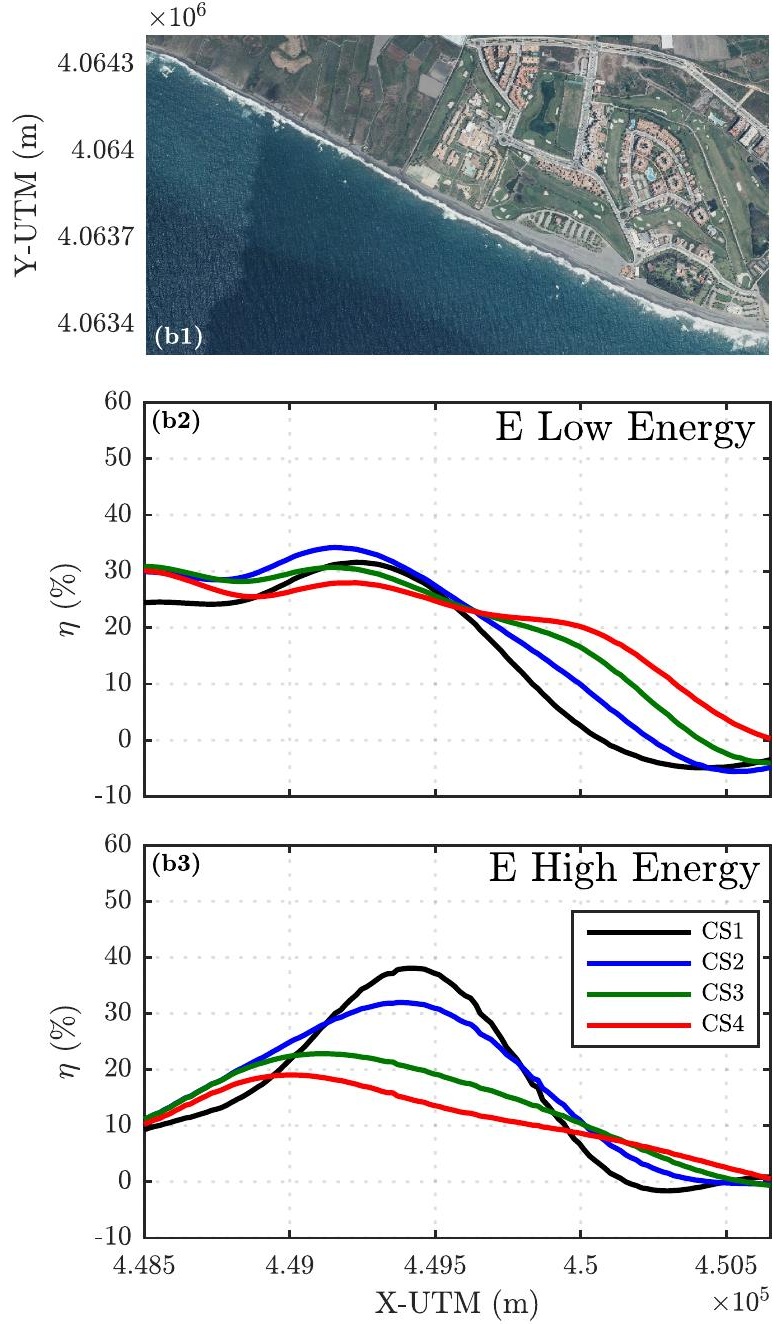
Figureçß1 Low Energy W Click here to download Figure: fig7.pdf-
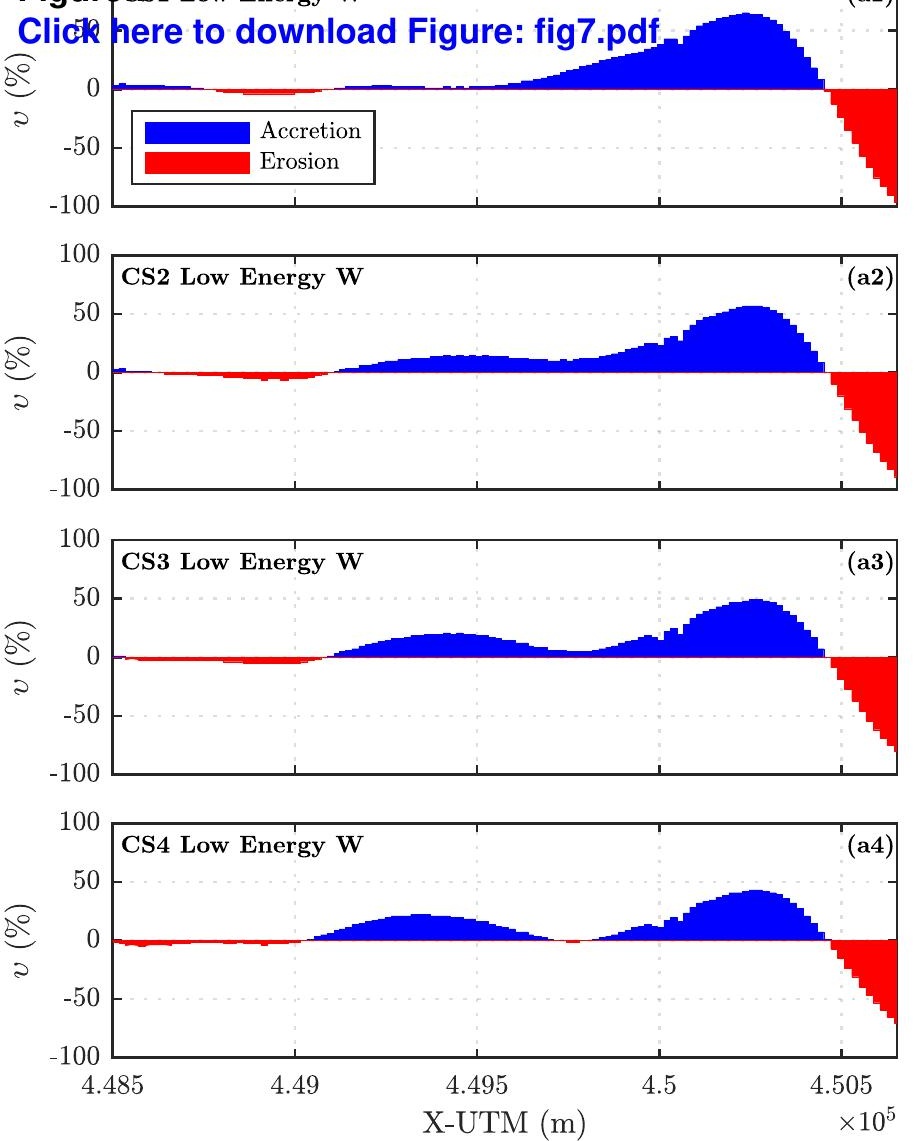

CS1 Low Energy E

(b1)
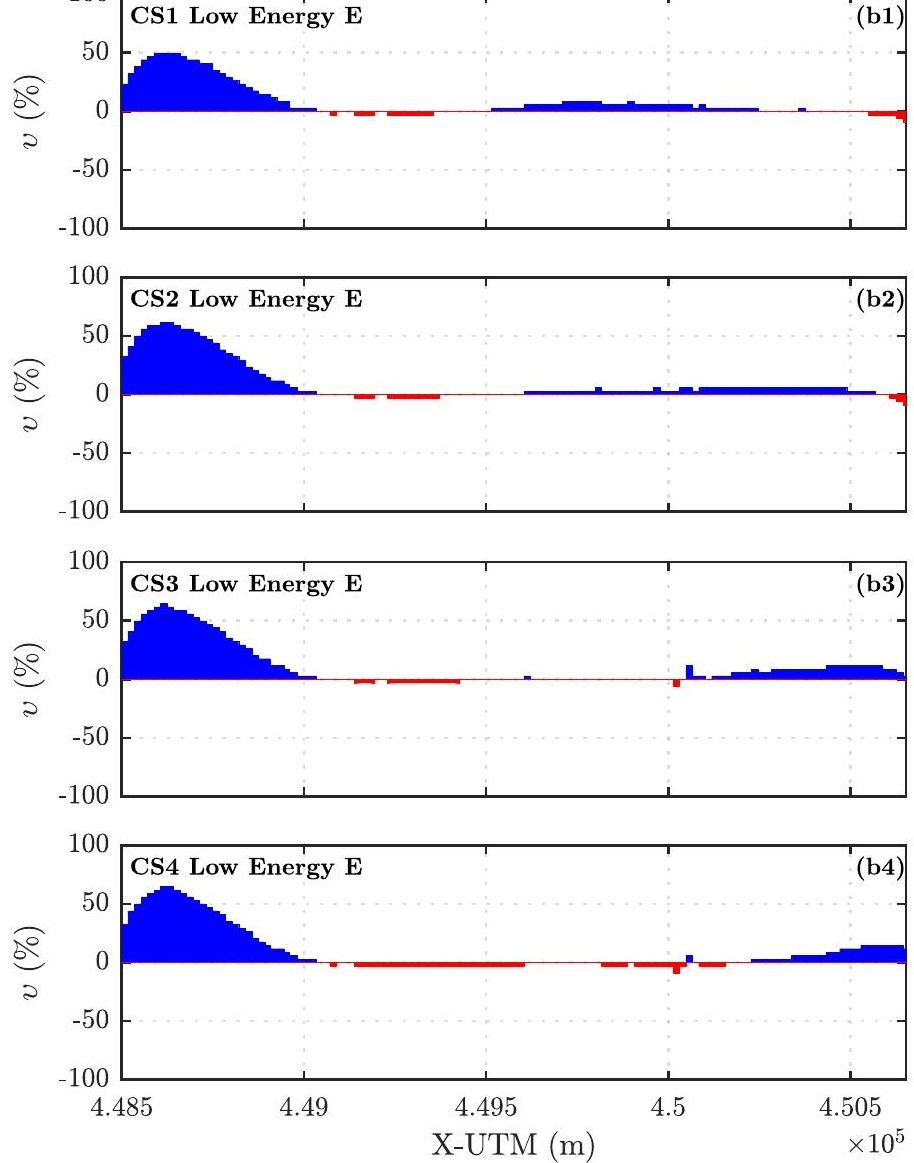
Figure(g1)

Clicks here to download Figure: fig9.pdf
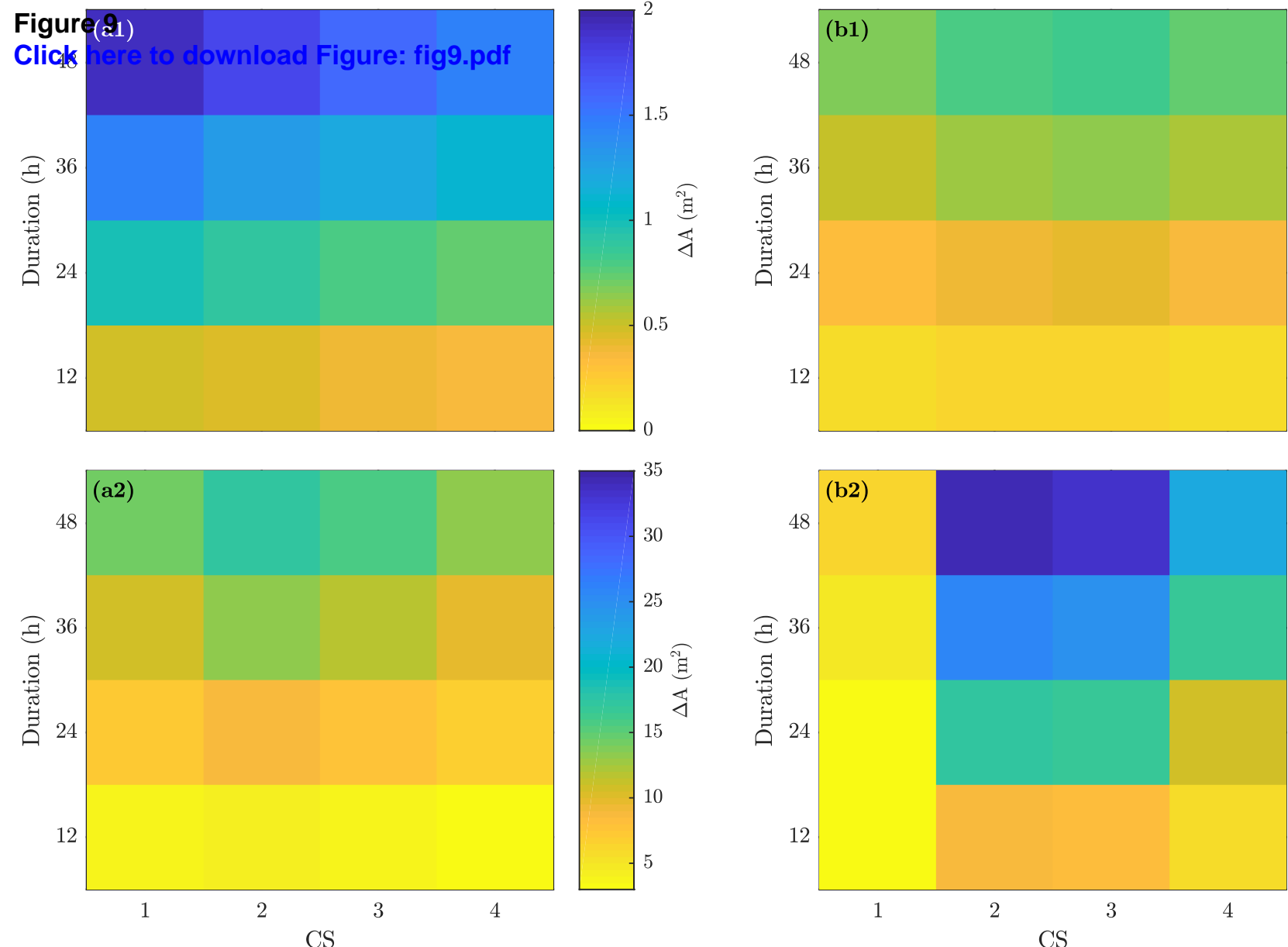
